\title{
Pangloss revisited: a critique of the dilution effect and the biodiversity-buffers-disease paradigm
}

\author{
S. E. RANDOLPH ${ }^{1}$ and A. D. M. DOBSON ${ }^{1,2}$ \\ ${ }^{1}$ Department of Zoology, University of Oxford, South Parks Road, Oxford OX1 3PS, UK \\ ${ }^{2}$ British Trust for Ornithology Scotland, Cottrell Building, University of Stirling, Stirling SFK9 4LA, UK
}

(Received 18 October 2011; revised 16 December 2011, 3 Fanuary and 4 Fanuary 2012; accepted 11 Fanuary 2012; first published online 16 February 2012)

\section{SUMMARY}

The twin concepts of zooprophylaxis and the dilution effect originated with vector-borne diseases (malaria), were driven forward by studies on Lyme borreliosis and have now developed into the mantra "biodiversity protects against disease". The basic idea is that by diluting the assemblage of transmission-competent hosts with non-competent hosts, the probability of vectors feeding on transmission-competent hosts is reduced and so the abundance of infected vectors is lowered. The same principle has recently been applied to other infectious disease systems - tick-borne, insect-borne, indirectly transmitted via intermediate hosts, directly transmitted. It is claimed that the presence of extra species of various sorts, acting through a variety of distinct mechanisms, causes the prevalence of infectious agents to decrease. Examination of the theoretical and empirical evidence for this hypothesis reveals that it applies only in certain circumstances even amongst tick-borne diseases, and even less often if considering the correct metric-abundance rather than prevalence of infected vectors. Whether dilution or amplification occurs depends more on specific community composition than on biodiversity per se. We warn against raising a straw man, an untenable argument easily dismantled and dismissed. The intrinsic value of protecting biodiversity and ecosystem function outweighs this questionable utilitarian justification.

Key words: dilution effect, biodiversity, community structure, disease risk, vector-borne diseases, helminths, rodent-borne infections.

\section{INTRODUCTION}

Over the past decade, conservationism and disease ecology have come together in a panglossian view that "all is for the best in the best of all possible worlds" (Voltaire, 1759), adding the utilitarian value of protection against zoonotic infectious disease to the intrinsic value of maintaining biodiversity. At a time of unprecedented pressures on natural resources and concomitant rates of biodiversity loss, and a consequential requirement for scientists to reinforce incentives for biodiversity conservation by outlining the ecosystem services it provides (Tilman et al. 1997; Tilman et al. 2006), the claimed reduction in zoonotic risk has emerged as a key exemplar of the value of biodiversity (Daszak et al. 2001; Ostfeld and LoGiudice, 2003; Diaz et al. 2006; Dobson et al. 2006; Johnson et al. 2008; Carlson et al. 2009; Keesing et al. 2010a). The converse, exacerbation of the global burden of disease by biodiversity loss, has been neatly linked with the other environmental bête noir, global climate change (Ostfeld, 2009). Both

* Corresponding author: Department of Zoology, South Parks Road, Oxford OX1 3PS UK. Tel: + 441865271241. Fax: + 441865 271240. E-mail: sarah.randolph@zoo.ox.ac. uk arguments are powerful levers for attracting funding from major agencies (Pongsiri and Roman, 2007). The basic idea arose within the discipline of malaria epidemiology (Macdonald, 1956) and was absorbed into ecology (Elton, 1958); because vertebrate species are differentially competent to support the transmission of various vector-borne pathogens, the distribution of arthropod vectors amongst different host species will have an impact on the transmission potential ( $R_{0}$ value) of the pathogens. This is the basis for 2 related but distinct phenomena: zooprophylaxis - active or passive use of animals to divert vector bites away from humans to protect the latter against infection (Hess and Hayes, 1970); and the dilution effect-lowering the abundance of infected vectors by diluting the assemblage of competent hosts with non-competent hosts and thereby reducing the probability that a vector feeds on a transmissioncompetent host. It is important, although empirically difficult, to distinguish between these outcomes as effects simply of reduced density, rather than of reduced relative abundance, of the competent host species (Begon, 2008).

In their simplest forms both zooprophylaxis and the dilution effect assume that the total abundance of vectors remains unchanged, which is likely only if the 
total abundance of bloodmeal hosts stays constant; zooprophylaxis reduces the contact rate of infected vectors with humans, but not necessarily their infection rate, whereas dilution (the replacement of competent hosts with non-competent ones) reduces vector infection rates, but not their contact rates with humans. If, however, these two effects are brought about through the addition of bloodmeal hosts, vector abundance is likely to increase with variable consequences for disease prevalence in the vectors. Addition of competent hosts will increase both vector abundance and vector infection rates, while addition of non-competent hosts will increase vector abundance even if it decreases vector infection rates; both may increase risk to humans. This is likely to occur for ticks, whose population and therefore vectorial potential is strongly affected by host density, but insect-borne disease systems are usually modelled as frequency-dependent transmission (per capita vector-host contact rate independent of host density), which can generate a protective effect of host diversity (Dobson, 2004) (but see results for malaria, below). Ultimately, the risk of zoonotic infections to humans depends upon the ratio of infected vectors per human. This risk will, in general, increase with more infected vectors in the environment, but in some situations vectors reduced in abundance by the removal of preferred hosts may switch their attention to humans, thus increasing risk. Hence vector abundance, vector infection rate, and the vectors' propensity to feed on humans all need to be quantified to determine the precise effects of zooprophylaxis or dilution.

In this review, we argue that while the dilution effect concept may be biologically sound in certain simple systems, in the complex systems typical of zoonoses and vector-borne diseases it is likely to apply only in occasional, often extreme, situations. The new mantra "biodiversity protects against infection" is an extension ad absurdum that simplifies and obscures reality. It should also be noted that, although some individual empirical studies specify the precise index of diversity purportedly related to risk of infection, the general arguments in favour of biodiversity (above) do not distinguish between functional diversity, species richness, relative abundance amongst species or indices that combine these (e.g. Shannon or Simpson indices of diversity).

THE PROMOTION OF THE CONCEPT: LYME BORRELIOSIS

The significance of livestock in diverting mosquito bites away from humans has been credited with contributing to the decline of malaria in northern Europe from the late 19th century (Reiter, 2008), despite doubts over the efficacy of such zooprophylaxis in Pakistan (Bouma and Rowland, 1995) and West African contexts (Bogh et al. 2002). The increase in vector density caused by higher cattle densities, even if a smaller proportion then feed on humans, has been shown by mathematical modelling (Sota and Mogi, 1989) and empirically (Bouma and Rowland, 1995) to result in higher malaria prevalence in humans. Likewise, where realistic values of vector mortality rates during host-questing decrease with increasing host abundance, zooprophylaxis may be ineffective, unless both types of hosts are distant from mosquito breeding sites or humans are protected from bites (Saul, 2003). The modelled basic reproduction number for Plasmodium vivax decreases with an increasing ratio of animal to human hosts and greater attraction of mosquitoes to animals, but only in the absence of a response of mosquito demographic rates (and therefore population outcomes) to host density (Nah et al. 2010).

It is, however, within the context of Lyme borreliosis that the concept of the dilution effect has been most heavily promoted in recent years. The bacteria are transmitted by tick species within the genus Ixodes across much of the northern hemisphere (Piesman and Gern, 2008). Because ticks feed only once per life stage (larva, nymph and adult), at least 2 stages must feed on a host to complete a full transmission cycle, one stage to acquire the infection and the next stage to donate infection to a new susceptible host. Epidemiologically, the most significant vector species are I. scapularis in $\mathrm{N}$ America, I. ricinus in Europe and I. persulcatus in Russia. The group of spirochaete agents, Borrelia burgdorferi s.1., comprises a growing list of recognized strains. Four (B. burgdorferi s.s., B. afzelii, B. garinii and B. spielmanii) are known to be pathogenic to humans, and each is differentially adapted to the many different vertebrate hosts upon which these ticks feed (Humair and Gern, 1998; Kurtenbach et al. 1998b; Hanincova et al. 2008). These include many species of rodents, insectivores, carnivores, lizards and birds in which long-lasting systemic infections are established and then transmitted back to ticks. Amongst ungulates, sheep develop only non-systemic infections yet support persistent transmission cycles between co-feeding ticks in the absence of other vertebrate species (Ogden et al. 1997), but deer appear to be solidly non-competent (Matuschka et al. 1992; Talleklint and Jaenson, 1994), despite unrepeated hints of amplification as larval and nymphal ticks co-feed on wild sika deer (Cervus nippon yesoensis) (Kimura et al. 1995). This pattern of transmission non-competence is mirrored exactly by the degree of borreliacidal activity of each host species' serum (Lane and Quistad, 1998; Kurtenbach et al. 1998c; Kurtenbach et al. 2006). Within this disease system, non-competent hosts have been credited with having a zooprophylactic effect by decreasing the infection prevalence in the tick population (Spielman et al. 1985; Matuschka et al. 1993; Matuschka et al. 2000) but, just as with malaria, 
they may in fact have the opposite effect. Risk to humans is usually related to the abundance of infected nymphal ticks (Glass et al. 1995), or simply of nymphs (Stafford (III) et al. 1998; Falco et al. 1999), because this stage is numerous but inconspicuous, and infection prevalence is typically above $10 \%$ in Europe and $>30 \%$ in northeastern USA (Hubálek and Halouzka, 1998; Horobik et al. 2007).

In principle it is clear how the proportion of infected ticks could be diluted; as new (noncompetent) species are added to the host assemblage, many infected tick bites will be 'wasted' (so-called encounter reduction) and also the proportion of ticks that may acquire the infection will decrease (transmission reduction) (LoGiudice et al. 2003; Keesing et al. 2006). It is not the proportion of infected ticks, however, but the absolute number that is the salient parameter in risk to humans. Any additional host species that feeds enough ticks to reduce the overall infection prevalence in questing ticks of the next stage by diverting them away from transmissioncompetent host species would be likely to increase the tick population density (and therefore the density of infected ticks, upon which transmission potential depends) by improving the chances of successful tick feeding. Thus the proportion of infected ticks declines, but their abundance may increase (van Buskirk and Ostfeld, 1995), which itself may enhance transmission potential amongst mice and so ameliorate the reduction in infection prevalence (Ogden and Tsao, 2009). This effect of additional hosts is particularly pertinent to ticks, being wingless, especially these sit-and-wait species that rely on host movement to effect chance encounters for feeding opportunities. Deer seem to have played this role in relation to several tick-borne pathogens in northern temperate regions, due to the fact that in the typical woodland habitats they are the most significant hosts for adult reproductive ticks and also feed significant numbers of the immature stages (Wilson et al. 1990; Gray et al. 1992). In the USA and Denmark, the increase in incidence of Lyme borreliosis has been correlated with the increasing density and distribution of deer (Spielman et al. 1985; Jensen and Frandsen, 2000; Jensen et al. 2000). In the northeastern USA, this was a result of reforestation with consequent enhanced biodiversity (Spielman et al. 1985). Likewise, in Sweden, increased abundance of nymphal ticks was attributed to 'a drastic increase in abundance and geographic range of roe deer' ('Talleklint and Jaenson, 1996). Whatever the proportion of larval ticks that feed on Borrelia-competent hosts, variously estimated as 96\% (Talleklint and Jaenson, 1994) in Sweden and ca. $40 \%$ in Switzerland (Burri et al. 2011), an increased tick population will generate greater numbers of infected nymphs. In parts of Europe, the risk of viral tick-borne encephalitis (TBE) has been positively related to the presence of deer (Zeman and Januska, 1999; Hudson et al. 2001;
Rizzoli et al. 2009), not because deer can transmit the virus, but because deer support $I$. ricinus populations. These empirical correlations are supported by the model predictions that increased deer abundance results in increased tick populations (Dobson et al. 2011; Dobson and Randolph, 2011). Similarly, new epidemics of Kyasanur Forest Disease in India appear to have been precipitated by a marked increase in human population during the 1950s: cattle newly introduced into forests, although not hosts for the virus, supported increased populations of ticks which infected humans as they gathered firewood (Hoogstraal, 1981).

The need for several host species with these complementary roles is now recognized as commonplace, especially in systems where the very hosts that contribute to maintaining and enhancing tick populations are typically not competent to transmit the pathogens between ticks; it applies to most I. ricinus-borne pathogens such as B. burgdorferi s.l., tick-borne encephalitis virus (TBEV) and Louping ill virus (Gilbert et al. 2001). A net effect of dilution caused by such hosts needs very careful quantitative analysis of field data, not just models, to be upheld. Nevertheless, according to best practice, theoretical studies should precede fieldwork in order to define the questions to be asked empirically.

TESTING THE CONCEPT

\section{Modelling the dilution effect for Lyme borreliosis}

The degree of dilution depends on the relative proportion of the vector population fed by different host species, which is highly variable geographically and between habitats. For the specific system of B. burgdorferi s.s., transmitted by $I$. scapularis in eastern N America, the particular model that was used to predict the negative effect of high mammalian diversity on the infection prevalence in nymphal ticks is guaranteed to give this result (LoGiudice et al. 2003). This highly influential model, based upon that of Giardina et al. (2000), assumes constant tick burdens on each given host, such that the density of ticks is always the sum of all $\mathrm{N} i \mathrm{~B} i$, where $\mathrm{N} i$ and $\mathrm{B} i$ are the abundance and tick burden, respectively, of the $i$ th host. This central assumption is mentioned in both these models, yet its validity is not investigated. In a subsequent model (Keesing et al. 2009), it is assumed that constant total numbers of ticks are fed, with all ticks that are not picked up by one host type being re-distributed to others. This assumption was not confirmed when experimental removal of lizards, a major host for I. pacificus larvae in California, resulted in an increased abundance of questing larval ticks (Swei et al. 2011). This is consistent with earlier indications from the UK that rather than ticks being in short supply, the proportion of the questing tick population fed per host depends more on the 
behaviour of individual hosts (Randolph and Steele, 1985) than on the availability of ticks. There is no evidence that hosts remove all, or even the majority of, larvae in a season; rather field evidence suggests that many ticks remain unfed, to die of energy exhaustion (Randolph and Steele, 1985; Randolph and Storey, 1999; Randolph, 2004; Brunner and Ostfeld, 2008).

Thus, the central assumption in the above models is invalid. Because they do not take account of the positively non-linear effect on tick population dynamics of increasing host density (as an increasing proportion of an increasing tick population finds hosts and survives) such relatively simple models cannot capture the full variation in tick abundance observed in the field (Brunner and Ostfeld, 2008). A more comprehensive tick population model (Dobson et al. 2011) was used to simulate the effects of gradually increasing the abundance of large hosts (i.e. deer) to double over 20, while the density of smaller hosts (set to feed fed $90 \%$ of larvae, $55 \%$ of nymphs and $0 \%$ of adults (Talleklint and Jaenson, 1994)) was held constant (Dobson and Randolph, 2011). Where deer numbers were initially low, the host increase caused a positively non-linear rise in the tick population (as measured by egg-laying females) that continued after host density was then held constant, reaching more than double the initial level. It is in just this kind of depauperate community that the dilution effect is predicted to have its effect (LoGiudice et al. 2003), yet the more complete model suggests the increase in tick density in this scenario would counteract any effects of dilution on the density of infected nymphs (not simply the infection prevalence in nymphs). A model specifically designed to investigate the point at which the extra number of hosts causes tick population amplification to negate the dilution effect, given various scenarios of host assemblages, would help to clarify the outcome of these counteractive forces.

Other models have captured the variability in outcome to be expected within such a biodiverse system. The early model of Rosa et al. (2003) showed that higher densities of non-competent hosts may have either a positive effect, by amplifying the tick population, or a dilution effect, by wasting tick bites. Only when a biologically questionable term, 'nonlinearity due to extended tick feeding', was included was dilution always seen, but then only at unrealistically high host densities when, presumably, almost all the tick population was indeed finding a host of one sort or another. Later models from the same team aimed to explain some highly equivocal experimental results derived from deer exclosures (Perkins et al. 2006); both empirical and theoretical results showed that when deer were excluded, prevalence of infection (this time with TBEV) in nymphs and the density of infected nymphs were higher only in small exclosures (Pugliese and Rosa, 2008). This is not entirely surprising, given the greater potential for other hosts to introduce larval ticks into the smaller exclosures (the very term used to characterize exclosure size mathematically). More general models, less constrained by specific artificial arrangements and untested assumptions, predict an outcome that varies between dilution and amplification depending precisely on mechanisms of inter-specific competition amongst hosts, rates of host contact with ticks and acquired resistance to ticks (Ogden and Tsao, 2009). These realistic features of tick biology are crucial if models are to be used to test the universality of the dilution effect.

\section{Empirical tests of the dilution effect for Lyme borreliosis}

More difficult but much more telling are empirical tests. Much of the supportive field data and analyses have been generated at a site in southeastern New York State, USA, but even within this narrow ecological setting the results do not always indicate the dilution effect as claimed. All too often general conclusions have been generated from limited data or extreme points extrapolated backwards from an observed high infection hazard under particular conditions to predicted lower hazard with presumed higher biodiversity.

One such example, highly cited in the dilution effect literature, substituted forest fragmentation for actual biodiversity, on the basis that in Indiana (USA) reduced mammalian species diversity and elevated densities of white-footed mice (Peromyscus leucopus) due to less competition for food have been associated with forest destruction and fragmentation into woodlots of $<2$ ha (Nupp and Swihart, 1998), with particularly high mice densities in woodlots of $<0.5$ ha (Nupp and Swihart, 1996). This is the presumed reason for the increased density of $I$. scapularis nymphs and their infection prevalence with $B$. burgdorferi s.s., observed in 4 out of 5 forest patches of ca. 1 ha compared with patches of ca. 3-7 ha (Allan et al. 2003) (Fig. 1). These smallest forest areas are equivalent to no more than 100-141 m on the side (if square), too small to house resident populations of deer or other larger species even though such hosts may pass through from nearby larger forest stands and deposit engorged adult ticks (necessary to sustain the tick populations). Higher numbers of questing nymphs observed over 1 month in summer may be due as much to the reduced rate of tick pick-up by scarce larger hosts (Randolph and Steele, 1985; Dobson and Randolph, 2011) as to the increased rate of larvae feeding on mice. While such tiny patches may represent small concentrations of risk to humans, they hardly represent a basis for the general extrapolation to the dilution effect driven by reduced biodiversity (Dobson et al. 2006). In any case this positive relationship between forest 

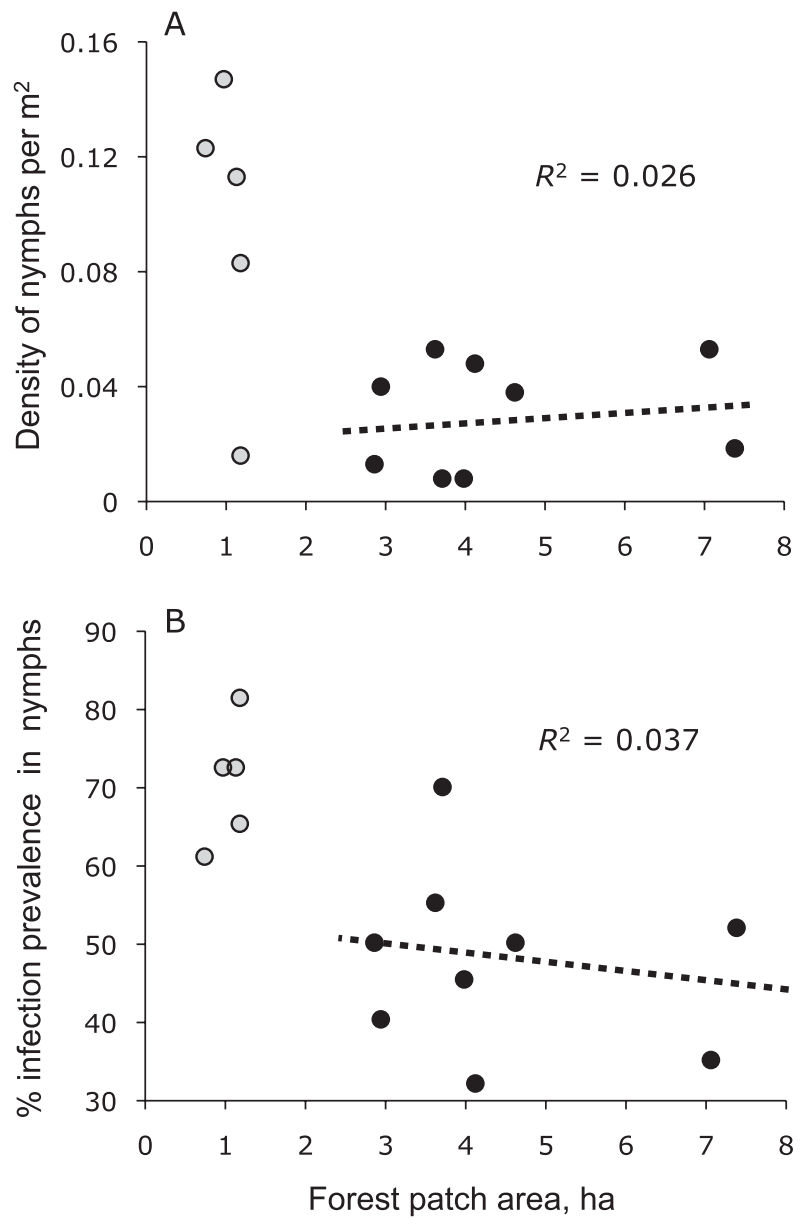

Fig. 1. Relationship between forest patch size and (A) the density of nymphal ticks, Ixodes scapularis, and (B) the infection prevalence of Borrelia burgdorferi in nymphs, at field sites in southeastern New York State, USA. The data are presented to reveal the non-significant trends over most of the range of forest patch sizes (filled circles). Redrawn from Allan et al. (2003), with permission.

fragment size $(0 \cdot 3-19$ ha) and nymphal infection prevalence was not repeated in more extensive samples taken across 3 neighbouring states (Connecticut, New Jersey and New York) (LoGiudice et al. 2008).

In another study, Ostfeld et al. (2006) disputed the positive effect of deer density on tick abundance, despite overwhelming prior evidence (see above), arguing instead that the abundance of acorns, whitefooted mice and eastern chipmunks are the primary determinants of temporal variation in Lyme borreliosis risk. Models were fitted to amalgamated data over several field plots from 13 annual observations of acorns, host and tick abundance and B. burgdorferi infection prevalence in nymphs. Not all potential predictors entered into the models, however, were measured independently for each replicate plot, i.e. were not compared at the same level of analysis; all the climatic variables and direct estimates of deer abundance were attributes of the entire study site but were treated as characteristics of individual plots. The failure of the analysis to acknowledge the
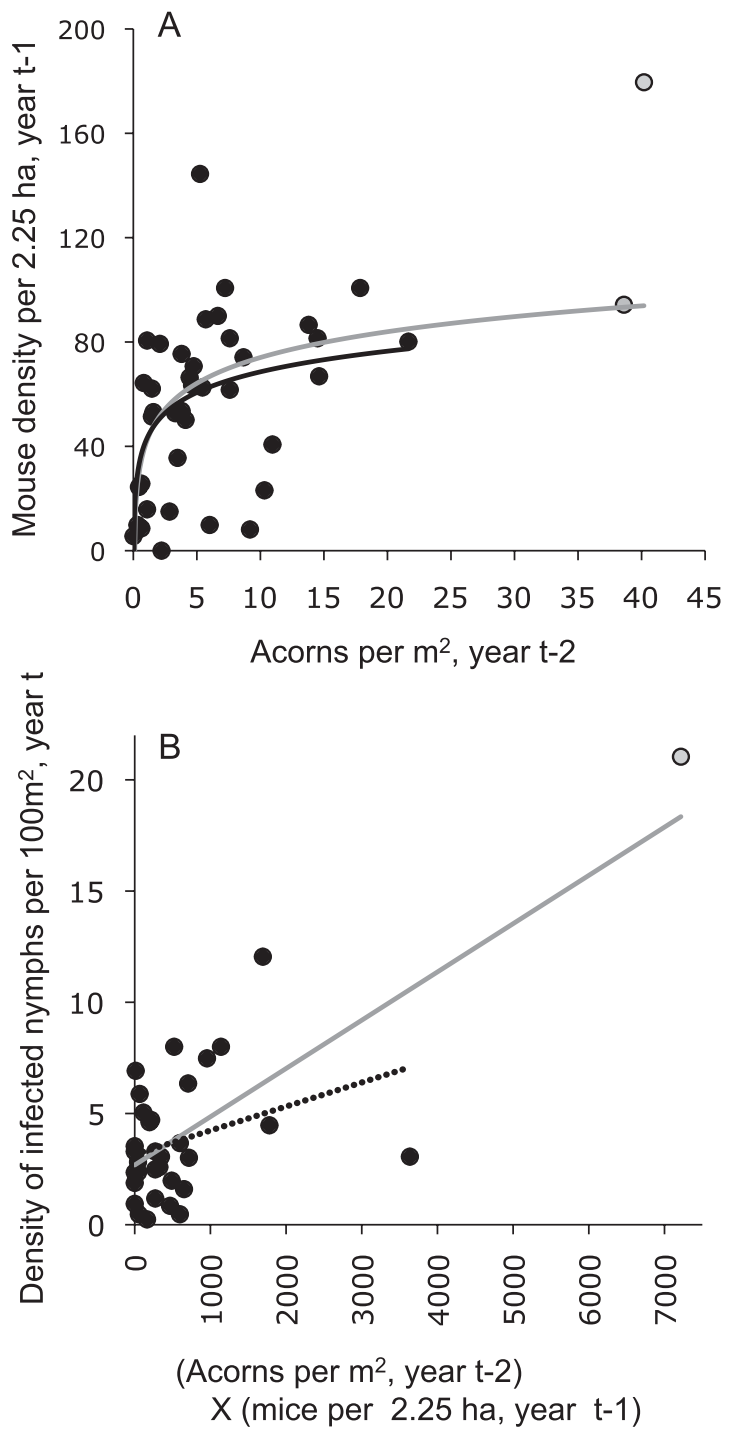

Fig. 2. Relationship between (A) mouse and acorn densities, and (B) density of infected nymphs and the product of previous acorn and mouse densities at field sites in southeastern New York State, USA. The inclusion of the right-hand extreme points (grey circles and lines) in (A) makes little difference apart from increasing the $R^{2}$ value from $0 \cdot 245(P<0 \cdot 05)$ to $0 \cdot 37$ $(P<0 \cdot 01)$, but in (B) the relationship is significant $\left(R^{2}=0 \cdot 57, P<0 \cdot 01\right)$ only with the outlier included (excluded, $\left.R^{2}=0 \cdot 087, P>0 \cdot 05\right)$. Redrawn from Ostfeld et al. (2006) (Figs 5A and 4A, respectively), with permission.

hierarchical structure of the data leads to inflated degrees of freedom for the climatic variables, which is classic pseudo-replication. Had the correct structure been identified, both visually in the graphs and statistically in the models, more light might have been thrown on the origin of the extreme outlier (Ostfeld et al. 2006), upon which the claimed relationship between rodent and infected tick abundance depends completely (Fig. 2). Only then could firm conclusions have been reached as to whether climatic variables and deer, or rodents and acorns, or a combination of these, are the principal determinants of Lyme disease 
risk. The conclusions as published explicitly undermine, quite possibly wrongly, much empirical evidence for the potential of deer to enhance tick populations and thereby to amplify Lyme disease risk despite their non-competence as $B$. burgdorferi hosts.

In a further analysis, both temporal and spatial data on chipmunk density and infestation levels of larval ticks on mice were again plotted on the same axes, and a poorly fitting linear regression was selected to conclude that increases in the former reduce the latter (Keesing et al. 2006). In fact, a negative power relationship is a better fit $\left(R^{2}=0 \cdot 30\right.$ rather than $\left.0 \cdot 22\right)$, which indicates not only that mean larvae per mouse varies markedly even at low chipmunk density, but also that low mean larvae per mouse can arise whatever the chipmunk density (Fig. 3). The low $R^{2}$ value even of the better model itself indicates that chipmunks are not good predictors of larval infestations on mice. Chipmunks actually produce almost as many infected engorged larvae or questing nymphs per hectare as do mice, while all non-mouse hosts together produce twice as many per hectare (LoGiudice et al. 2003). Although these statistics change somewhat when other less commonly studied vertebrates, such as shrews, are included (Brisson et al. 2008), nevertheless adding chipmunks (rather than replacing mice with chipmunks), even if they diverted some larvae from mice, would have little effect on the density of infected nymphs. A similar conclusion arises from experimental data from a large forested area of Connecticut, independent of detailed knowledge of each host species; mice evidently contributed only about half the infected nymphs, with the rest coming from alternative host species (Tsao et al. 2004).

There are, however, some specific situations where competent transmission hosts are more or less completely replaced, rather than augmented, by noncompetent host species, and enzootic cycles can be severely limited in those circumstances. This is thought to account for the much lower prevalence of $B$. burgdorferi s.s. in nymphal ticks in the southeast, compared with the northeast, of the USA (Piesman, 2002), where refractory lizards rather than rodents are the major hosts for immature I. scapularis (Apperson et al. 1993). This constitutes a change in host assemblage, but not necessarily an increase in vertebrate diversity. Similarly, although rodents are not replaced, where pheasants are locally very abundant in southern England, they feed such a large proportion of the nymphal I. ricinus population that $B$. afzelii, which is not transmitted by birds, evidently cannot persist (Kurtenbach et al. 1998b). Neither ticks nor small rodents showed any infection with $B$. afzelii, despite the high abundance and competence of these hosts for this Borrelia strain. In this case, the end point of $R_{0}<1$ had evidently been reached, thereby eliminating infection with this one

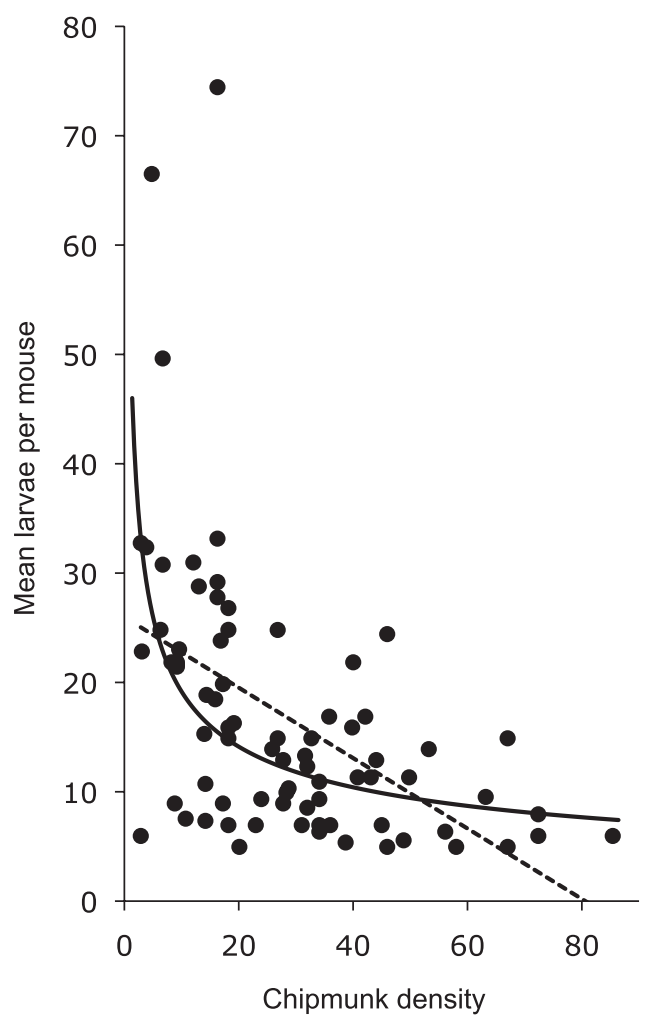

Fig. 3. Relationship between chipmunk density and mean larval burdens per mouse at field sites in southeastern New York State, USA. As well as the original linear model (dashed line, $R^{2}=0 \cdot 22$ ), the more explanatory power model (solid line, $R^{2}=0 \cdot 30$ ) is shown. Redrawn from Keesing et al. (2006), with permission.

strain altogether, but leaving other strains, B. garinii, $B$. valaisiana and B. burgdorferi s.s., which are transmissible via birds (Humair et al. 1998), including pheasants (Kurtenbach et al. 1998a). Pheasants feed relatively few larvae (Hoodless et al. 2002), however, so that amplification of these Borrelia strains takes place as nymphs feed on these large ground-foraging birds, leaving infection prevalence for each strain at $1-3 \%$ in questing nymphs (compared to the more usual ca. $10 \%$ ), but up to $10 \%$ in questing adults (Kurtenbach et al. 1998b). Thus a high density of one particular host type, but hardly an index of high biodiversity, can cause dilution in one fraction of the tick population, and zooprophylaxis given that humans are most commonly bitten by the ticks in that fraction (questing nymphs). This particular case is largely artificial, created by unnaturally high densities of pheasants released from game farms in the interests of shooting. Usually, hosts large enough to carry very high individual infestation levels of ticks exist at low population densities and so do not necessarily feed any greater fraction of the total tick population than do smaller, abundant hosts such as rodents (Talleklint and Jaenson, 1994; Craine et al. 1995).

The western fence lizard in northern California, however, is both non-competent to transmit 
B. burgdorferi s.l. and so abundant as to feed almost all of the larval and nymphal I. pacificus in some areas, thereby significantly reducing the infection prevalence in adults compared with nymphs (Lane and Quistad, 1998). As humans are commonly bitten by adult $I$. pacificus in northern California (Clover and Lane, 1995), lizards might thus offer an element of zooprophylaxis. Experimental removal of this host, however, generated some mixed results, some of which were contrary to the predictions of the dilution effect theory (Swei et al. 2011), but which is to be expected from complex natural tick-host-Borrelia interactions. First, there was an immediate significant increase in questing larvae, suggesting that those not fed by lizards did not switch at once to alternative hosts species (see above). This was consistent with the lower density of questing nymphs the following year. Secondly, of the two mammal species that were monitored and consistently infested by substantial numbers of immature ticks, deer mice (Peromyscus maniculatus) did not feed more larval ticks after lizard removal whereas wood rats (Neotoma fuscipes) did, but this was significant relative to changes on the control plots only for female rats, and sufficient to accommodate only ca. $5 \%$ of the excess questing larvae. As there was no detectable effect of lizard removal on the prevalence of infection with $B$. burgdorferi s.s. in nymphs the following year, the overall density of infected nymphs decreased then. These results from California provide an example of a specific natural host assemblage in which the most abundant host for immature ticks is non-competent, but nevertheless may increase disease risk by maintaining high vector densities, just as deer appear to do in the northeastern states and in Europe. The outcome is likely to be due to the effects of reduced host (lizard) density, without providing any test for a dilution effect driven by changing biodiversity (Begon, 2008). The individual effects, however, are clearly incompatible with many aspects underpinning the concept of the dilution effect of high biodiversity that has been promoted by studies of Lyme borreliosis.

In conclusion, Lyme borreliosis is one of the most robust and biodiverse zoonotic disease systems known, even in the New World (Brisson et al. 2008) with its more limited genetic and phenotypic diversity of B. burgdorferi s.l. than in the Old World (Kurtenbach et al. 2006) where a number of tick species act as vectors amongst a wide variety of competent vertebrate transmission host species (Gern et al. 1998). It is strange, therefore, that it should have spawned the prevailing view that high biodiversity habitually protects against zoonotic diseases of all sorts. It is predicated upon, and indeed dependent upon (Ostfeld and LoGiudice, 2003), the assumption that the density of competent hosts species always declines with increasing host diversity sufficiently to reduce the density of infected nymph, as if there were some universal (biologically
Table 1. Attributes necessary for the dilution effect in vector-borne disease systems, taken from Ostfeld and Keesing (2000b)

\begin{tabular}{|c|c|}
\hline $\begin{array}{l}\text { Condition to promote } \\
\text { dilution }\end{array}$ & Effect of alternative condition \\
\hline $\begin{array}{l}\text { Generalist vector } \\
\text { must bite a wide } \\
\text { range of host species }\end{array}$ & $\begin{array}{l}\text { If vectors feed preferentially on } \\
\text { the most competent hosts, the } \\
\text { addition of other hosts will not } \\
\text { decrease the infection prevalence } \\
\text { in vectors incrementally }\end{array}$ \\
\hline $\begin{array}{l}\text { Reservoir competence } \\
\text { (the ability of a } \\
\text { particular host } \\
\text { species to infect a } \\
\text { vector) must vary } \\
\text { among host species }\end{array}$ & $\begin{array}{l}\text { Additional competent reservoirs } \\
\text { will contribute to a 'rescue effect', } \\
\text { allowing relatively constant } \\
\text { infection prevalence in vectors } \\
\text { even if host assemblage fluctuates }\end{array}$ \\
\hline $\begin{array}{l}\text { The most competent } \\
\text { reservoir host tends } \\
\text { to be dominant in } \\
\text { the community, } \\
\text { thereby feeding the } \\
\text { greatest proportion } \\
\text { of the vector } \\
\text { population, and } \\
\text { being present in } \\
\text { both species-poor } \\
\text { and species-rich } \\
\text { communities }\end{array}$ & $\begin{array}{l}\text { Additional non-competent hosts } \\
\text { that feed many vectors, especially } \\
\text { those essential for vector } \\
\text { population maintenance } \\
\text { (e.g. adult ticks), will increase the } \\
\text { abundance of vectors, off-setting } \\
\text { any decrease in infection } \\
\text { prevalence } \\
\text { Additional non-competent hosts } \\
\text { that prey upon or compete with } \\
\text { reservoirs, will exacerbate the } \\
\text { dilution effect }\end{array}$ \\
\hline $\begin{array}{l}\text { Infection of vectors } \\
\text { must be acquired } \\
\text { principally via bites } \\
\text { on infectious hosts } \\
\text { rather than } \\
\text { transovarially from } \\
\text { the previous } \\
\text { generation of vectors }\end{array}$ & $\begin{array}{l}\text { A high degree of vertical } \\
\text { transmission will maintain the } \\
\text { infection prevalence in the vector } \\
\text { population }\end{array}$ \\
\hline
\end{tabular}

determined) co-variation between competence and density in bio-depauperate environments. In fact, neither the theoretical nor the empirical basis for the assumption stands up to close scrutiny (see below, also, for a brief discussion of the immuno-ecological trade-off hypothesis). Results from large-scale interstate correlational studies (Ostfeld and Keesing, 2000a) and the latest experiments in California, where the "Lyme disease system behaves differently" (Swei et al. 2011), undermine the generality of the mantra "diversity protects against infection risk" (Keesing et al. 2010a). Indeed, only those systems that conform to certain conditions (Ostfeld and Keesing, 2000b) (Table 1) are likely to obey this panglossian claim, and these may be more or less exceptional even amongst tick-borne diseases in particular and vector-borne diseases in general, let alone other directly transmitted disease systems.

EVIDENCE AGAINST THE DILUTION EFFECT

FROM OTHER TICK-BORNE DISEASE SYSTEMS

The tick-borne bacterial agents of human ehrlichiosis (Ehrlichia chaffeensis and E. ewinigii) depend on 
white-tailed deer (Odocoileus virginianus) as both the principal reservoir host and the major source of bloodmeals for the vector tick Amblyomma americanum (Allan et al. 2010; Paddock and Yabsley, 2007). Although indigenous, these deer have acted as an 'invasive' species during the second half of the 20th century, re-colonizing large parts of the USA following re-forestation (Spielman et al. 1985), reaching forest-damaging densities in some places (Ward and Mervosh, 2008). Environmental changes that favour deer may therefore strengthen transmission cycles of Ehrlichia; invasion of many forests in eastern $\mathrm{N}$ America by Amur honeysuckle (Lonicera maackiii) appears to be one such change (Allan et al. 2011). A significant association was found between the presence of honeysuckle, overall vegetation density, deer density and the density of nymphal ticks infected with E. chaffeensis. When honeysuckle was cleared, densities of deer and infected nymphs were reduced to levels that matched those in naturally non-invaded areas. There was no difference in off-host tick survival that might be due to abiotic conditions associated with the much (ca. 18 times) denser under-storey in honeysuckle stands, but a greater proportion of tick bloodmeals were taken from deer where honeysuckle was abundant, which was in turn associated with a higher density of infected nymphs. Where deer provide crucial bloodmeals for ticks (true also of I. scapularis), and in this case also act as reservoirs for Ehrlichia spp, their enhanced presence evidently increases the risk of human disease. In a reversal of cause and effect, over-browsing of palatable plant species by over-abundant deer allows browseresistant invasive shrubs (e.g. Japanese barberry, Berberis thunbergii) to dominate; the observed increased density of adult and nymphal $I$. scapularis appears to be due to the resultant dense thickets that supply shelter and food for birds and mammals, including many important tick hosts, rather than only to the primary factor of high deer density (Elias et al. 2006), because when barberry was controlled both tick abundance and their prevalence of infection with B. burgdorferi were reduced (Williams et al. 2009).

Both sets of results emphasize the positive relationship between deer abundance and the risk of various tick-borne diseases, in contrast to the negative dilution effects claimed for this host species in the original work on Lyme borreliosis (above). They highlight the diversity of outcomes to be expected from the diversity of precise biotic and abiotic interactions specific to each disease system. Widespread invasion by another exotic plant, Japanese stiltgrass (Microstegium vimineum), for example, may reduce the abundance of $A$. americanum and Dermacentor variabilis ticks as they suffer increased mortality rates due to raised temperature and reduced humidity in plots dominated by this particular plant (Civitello et al. 2008). Although these examples may be characterized as biodiversity loss through floristic homogenization, at least some involve increased faunistic diversity and each involves a distinct mechanistic pathway between environmental changes and disease risk, leading to disparate outcomes. These need to be recognized explicitly rather than shoehorned into a single claim for the universal health benefits of biodiversity (Pongsiri et al. 2009).

EVIDENCE FOR AND AGAINST THE DILUTION EFFECT FROM INSECT-BORNE DISEASE SYSTEMS

Amongst insect-borne diseases, West Nile Virus (WNV) in the New World has emerged as the strongest candidate to provide evidence for the dilution effect, despite its reliance on a highly diverse array of mosquito vectors and avian hosts in many parts of the world. Ambivalent conclusions rest on coarse correlational studies at various spatial scales looking for negative relationships between bird diversity and human case numbers, but without taking account of the multiple, but hitherto poorly quantified, mechanistic processes that operate between ecological conditions and the final outcome of public health interest. The first evidence came from the negative relationships between human WNV cases and the diversity and abundance of non-competent nonpasserine birds within and among counties in Louisiana, USA (Ezenwa et al. 2006). Conversely, the predicted positive relationship between competent passerine species richness and infection rates was not seen, possibly masked by the ubiquity of passerine species. Its absence is, in any case, not inconsistent with the idea that non-competent hosts could dilute the force of the avian transmission cycle. The authors themselves, however, point out a number of gaps in the evidence that allow alternative interpretations. Many other environmental variables, including all abiotic conditions and the diversity of mammalian bloodmeal hosts for mosquitoes, were omitted from the analysis; the avian abundance was possibly inadequately quantified and did not include nestlings, making it difficult to distinguish unequivocally between a density-dependent dilution effect or a truly biodiversity-driven frequency-dependent dilution effect; the single measure of avian abundance did not coincide seasonally with the mosquito surveys. Furthermore, many bird species suffer high mortality from WNV infection, so that the claimed causality in the observed relationship might in fact be reversed.

Results from another correlational study over a much wider geographical range in eastern USA, that took into account possible co-variates of human WNV cases (such as climate, vector species, human socio-economic factors and urbanization), indicated that increased bird diversity did not cause a reduction in either transmission from birds to mosquitoes, or encounter between infected mosquitoes and 
competent hosts (Swaddle and Calos, 2008). Absolute and relative abundance of competent hosts were equally good at explaining human WNV incidence, leaving both density- and frequencydependent explanations possible and indistinguishable. One set of results indicated more human cases associated with greater relative diversity of nonpasserines, thereby implicating non-passerines as more competent reservoirs than previously thought (Swaddle and Calos, 2008). Equally ambivalent results on the one hand claimed as evidence for the dilution effect (Allan et al. 2009) and on the other hand claimed as providing no evidence (Loss et al. 2009), are bedevilled by the lack of detailed quantitative knowledge of the specific vector-host-virus mechanistic relationships under natural conditions. A significant aspect appears to be marked feeding preferences by mosquitoes even amongst the commonly dominant passerine species, disrupting any simple relationship between avian community structure and WNV transmission potential (Kilpatrick et al. 2006). Taking this into account, the 'community-wide force of infection' was calculated, and an interaction between this term and avian diversity was best able to predict the observed infection rate in Culex mosquitoes in suburban Chicago, Illinois (Hamer et al. 2011). American robins Turdus migratorius, house sparrows Passer domesticus and house finches Carpodacus mexicanus were, in that order, most significant in driving the force of infection, while 15 other species present at high-diversity sites did not habitually provide mosquito bloodmeals (Hamer et al. 2011). In addition, vector-free transmission amongst different types of terrestrial vertebrates (Kostiukov et al. 1986; Hubálek and Halouzka, 1999; Komar et al. 2003; Miller et al. 2003; Sbrana et al. 2005) involving direct contact, fecal contamination or ingestion of infected corpses, could theoretically augment virus circulation (Hartemink et al. 2007), but has so far been ignored when testing the dilution effect in WNV systems.

Thus it seems that very similar sorts of observations may be used to argue either for or against the dilution effect, depending not on unequivocal evidence but on the authors' initial predispositions. It is likely that dilution may indeed occur in some circumstances, but is by no means the only outcome of increased biodiversity. Furthermore, WNV offers a good example of transmission potential being affected by community composition, rather than biodiversity per $s e$; the identity of each suite of species is evidently significant. An important theoretical advance is the incorporation of the impact of vector diversity on the outcome, dilution or amplification, of WNV transmission (Roche and Guégan, 2011). The high diversity of mosquito species in the New World (Turell et al. 2005), together with nonrandom avian host selection (above), contributes to transmission cycles and the spectacular epidemic of

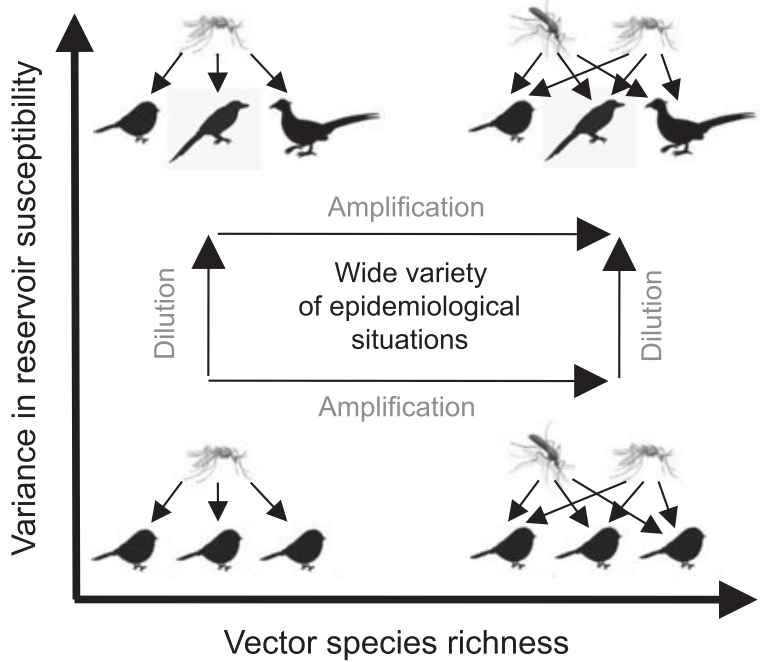

Fig.4. Dual effects of the richness in reservoir and host vector species on the transmission of vector-borne pathogens of zoonotic origin. As variance in reservoir competence increases in species-rich host communities, a decrease in the prevalence of disease pathogens in the vectors may be observed (dilution effect). On the other hand, in species-rich communities of vectors, a larger proportion of vectors, even if poorly competent, can acquire the pathogen from infectious hosts and then amplify the transmission of the disease to susceptible hosts (amplification effect). In natural conditions, these two antagonistic effects can lead to contrasting epidemiological situations depending on the characteristics of the local ecosystems and their biological diversity. Reproduced from Roche and Guégan (2011), with permission.

the early 21 st century (CDC, 2007, http://www.cdc. gov/ncidod/dvbid/westnile/), in contrast to the much more limited range of competent species and smaller sporadic outbreaks in southern Europe (Murgue et al. 2001). A new multi-host/multi-vector model indicates that increased richness of vector species, and therefore increased vector abundance, may compensate for any wasted contacts between vectors and poorly competent vertebrate hosts, and may even result in amplification rather than dilution (Roche and Guégan, 2011) (Fig. 4). These authors point out that even within a single vector species, mosquito abundance will increase with blood-meal host abundance, whether the latter is competent or not, just as in the tick-borne disease systems (above). Indeed, "local richness and composition in host reservoirs and vectors may lead to different combinatorial effects of disease transmission", whatever the relative competence levels of vertebrate and vector species (Roche and Guégan, 2011). Amongst many other disease systems that rely on multiple vector species, viruses that cause dengue and chikungunya are each transmitted differentially by 2 species of Aedes mosquitoes with different host relationships in each part of their increasingly extensive ranges. The arrival of $A$. albopictus in the New World, joining 
the longer-established $A$. aegypti, may be contributing to the emerging epidemics of dengue there (Marina et al. 2011). Similarly, both mosquito species transmit chikungunya virus in tropical regions, that caused dramatic epidemics on Indian Ocean islands in the early years of this century, while the 2007 epidemic in northern Italy depended entirely on $A$. albopictus. In the veterinary field, the erstwhile uniquely southern African strain of blue tongue virus (BTV8) has been maintained in northern Europe since 2006 by a new suite of Culicoides midges whose feeding habits and vector competence, and therefore variable contributions to maintaining transmission, have not yet been well characterized.

EVIDENCE FOR DILUTING OR AMPLIFYING

EFFECTS OF BIODIVERSITY FROM OTHER

INDIRECTLY TRANSMITTED PARASITE SYSTEMS

To support the generality of the conclusions drawn from vector-borne disease studies, Keesing et al. (2010) cite studies on the effects of changing host community structures on parasites with complex life cycles that include intermediate hosts and free-living stages. Amongst these, of greatest medical and veterinary importance are the helminths, which offer the valuable element of experimentation to augment the above observational studies. When the community structure of snails, of which only Biomphalaria glabrata acted as intermediate host for Schistosoma mansoni, was changed from single- to mixed-species by adding 2 non-host snail species (but maintaining a constant density of $B$. glabrata), infection prevalence declined by $25-50 \%$, and $60-80 \%$ fewer cercariae were produced per snail (Johnson et al. 2009). The former effect may have been due to a diversion of snailinfective miracidia away from target hosts to nonhosts (a 'decoy' effect, equivalent to Keesing et al's (2006) 'encounter reduction'), while the latter may reflect a competition-mediated reduction in resources available for cercarial production. These effects, however, are potentially offset by an observed increase in host fitness, double the mean per capita egg production by $B$. glabrata in heterospecific compared with monospecific host communities, as uninfected snails escaped parasite-induced castration. As long as this increased snail fitness exceeds the cost of competition, within the whole system under natural conditions the intermediate host density may increase, thereby enhancing overall cercarial production and thus risk to humans.

Such parasite-mediated facilitation has been observed amongst other helminths, for example the trematode Ribeiroia ondatrae transmitted between snails, amphibians and amphibian-eating birds (Johnson et al. 2008). Experimental manipulation of amphibian host community structure (competent Bufo americanum with or without low-competent
Hyla versicolor and Rana clamitans at different relative densities) allowed the authors to conclude that "the reduction in parasite transmission was specifically due to the presence of a low-competency host, rather than to a generic increase in host species richness", emphasizing the importance of the specific composition of the host community (as distinct from biodiversity per se). Again, however, the competent host enjoyed fitness benefits, specifically fewer limb malformations and higher survival, which was considered likely to offset any negative effects of interspecific competition within more diverse host communities. Given the time constraints on host finding by cercariae, increased competent host abundance is likely to enhance parasite transmission in the long term. In this latter example, the interest lay in the potential conservation of a susceptible host species, which was evidently achieved by the addition of alternative hosts, rather than on the potential for parasite transmission per se, as in zoonotic disease systems.

The significance of the precise species composition and relative abundance of members of the ambient community, rather than simply diversity, has been emphasized for other helminth parasites with complex life cycles. Nevertheless it is true that the more diverse the community, the more likely it is to include zooplankton that act as predators on infective cercariae, non-host decoys or alternative hosts, all of which evidently act additively to reduce parasite loads in any one intermediate host of interest (e.g. digenean trematodes Himasthla elongata in cockles Ceratoderma edule) (Thieltges et al. 2009a). In some cases, these sorts of effects may be caused by invading alien species that happen to act as non-host decoys, thereby benefiting native host species (Thieltges et al. 2009b).

Given the complexity typical of many indirect parasite life cycles, the potential for a wide variety of effects of changing host diversity on parasite transmission rates is large, with many examples of negative relationships between biodiversity and disease risk entering the literature. As emphasized by Johnson and Thieltges (2010), however, this is not an inevitable relationship; converse positive relationships are possible and documented for both vectorborne microbes (see above) and complex life-cycle parasites. For example, the infection prevalence of the myxozoan parasites (Myxosoma cerebalis, that causes whirling disease in salmonid fish) in tubificid intermediate hosts (Tubifex tubifex) was higher in the presence of a non-host tubificid (Limnodrilus hoffmeisteri) than in monocultures (Steinbach Elwell et al. 2009). Taking into account complex species-specific density-dependent effects of adult tubificid growth rates and reproduction, the authors suggest that the presence of L. hoffmeisteri may have released T. tubifex from intraspecific interactions that limited infection in high-density monocultures. 
Another system that yielded results contrary to the dilution hypothesis brings us back to vectorborne infections, but this time the transmission of barley and cereal yellow dwarf viruses (B/CYDV) by aphids amongst grasses, including many crop species (Borer et al. 2009). Annual grasses are highquality hosts that support elevated aphid populations and have relatively high virus reservoir competence, while perennial grasses sustain lower aphid populations and have lower reservoir competence, but are important as between-season virus reservoirs. Forbs (herbaceous flowering plants) are non-hosts, supporting neither aphids nor B/CYDV, but they compete with host grasses for soil and light. The final element is vertebrate herbivores, not within the transmission cycle in any way, but as selective grazers, removing forbs and stimulating plant regrowth, thereby increasing aphid colonization (Borer et al. 2009). When these consumers were excluded from the system, B/CYDV infection prevalence decreased from $18 \%$ outside the exclosures to $5 \%$ inside, i.e. consumers actually allowed greater infection prevalence. This does not in fact contradict the view that consumers of animal hosts (predators) control infectious diseases by removing infected hosts, because that arises when consumers selectively remove infected hosts (Packer et al. 2003), the very opposite of this B/CYDV system. Here the grazers had no effect on host species richness, evenness or Shannon diversity (i.e. infection prevalence was high in the presence of high host diversity), but they did increase the relative abundance of high-quality hosts, shifting the floristic composition towards one more favourable for virus transmission. Again, the effect of an additional specific element, consumers, to the community varies between systems, undermining the generality of the simple mantra "biodiversity protects against infection". A similar conclusion arose from earlier experiments with this cereal virus: "host diversity was less important for virus epidemiology than the presence [but not proportional abundance] of one highly suitable host species" (Power and Mitchell, 2004). In the presence of a highly suitable host species, wild oats Avena fatua, substantial pathogen spillover into other host species occurred, resulting in lower biomass of 2 other grass species in the presence of both $A$. fatua and the virus, i.e. pathogen-mediated apparent competition (Holt and Lawton, 1994). This phenomenon itself has consequences for community structure and diversity attributes (beyond the topic of this review), but in the present argument the key point is the ability of one additional host species to determine infection prevalence in other species and thereby drive epidemics, whether amongst wildlife hosts (e.g. red and grey squirrels Sciurus vulgaris and S. carolinensis, respectively-Bruemmer et al. 2010) or involving humans (zoonoses of many types).
LIMITED EVIDENCE FOR DILUTING EFFECTS OF BIODIVERSITY FROM DIRECTLY TRANSMITTED INFECTIOUS DISEASE SYSTEMS

The extension of the dilution effect to directly transmitted diseases is seen as a significant step with broad conservation implications, because "linking human health to biodiversity could be just the [tangible human] benefit for gaining the public's support of conserving biodiverse ecosystems" (Dizney and Ruedas, 2009). Since rodent-borne hantaviruses emerged from obscurity in the mid-1990s, they have become a favourite example in this political endeavour. Human infection (resulting in haemorrhagic fever with renal syndrome in the Old World, and hantavirus pulmonary syndrome in the New World, often with severe and fatal clinical outcomes) occurs through contamination with infected rodent urine and feces. Risk, therefore, increases with the density of infected rodents, abiotic conditions favourable for prolonged survival of the virus in the environment, and human behaviour likely to maximize contact with rodents, which can be higher among low-income households (Linard et al. 2007).

Most attention has been focused on determinants of the abundance of infected rodents, for which in Europe there is marked geographical variation (Vapalahti et al. 2003). In northern Fennoscandia, voles Myodes glareolus, the host of Puumula virus (PUUV), show 3-4 year population cycles probably driven by specialist predators (Hanski et al. 1991) within relatively homogenous landscapes (Dalkvist et al. 2011), with intense transmission amongst rodents and also to humans associated with these regular high rodent densities (Vapalahti et al. 2003). In this case, high predator abundance causes rodent population declines as part of the natural predatorprey cycle, but an argument that links the presence of predators (sensu Packer et al. 2003; Ostfeld and Holt, 2004) with reduced risk of hantavirus infection would be disingenuous within such a system of short-term cycles. In temperate Europe, in contrast, rodent populations are more stable but punctuated by peaks driven by occasional mast years (when oak and beech seed crops are unusually heavy). This leads to irregular epidemics synchronized over large areas, which can be forecast from high temperatures in the preceding summer (year t-2) and autumn (year t-1) (Tersago et al. 2009). Infection risk can be correlated in space and time with rodent population dynamics, in both the long- and short-term (Tersago et al. $2011 b$ ), and also with individual rodent behaviour and physiology associated with reproduction at an even finer scale, leading to seasonal shifts in transmission mechanisms (Tersago et al. 2011a). Spatial variation in PUUV prevalence in voles and human case incidence within Belgium, lower in the north than the south, has been related to local climate and habitat fragmentation effects on vole density, 
possibly with a threshold effect, and the relative proportion of non-host wood mice (Apodemus sylvaticus) in the rodent communities, i.e. a dilution effect (Tersago et al. 2008). Across Europe, however, different rodents are primary hosts for different hantaviruses (Vapalahti et al. 2003) and therefore greater rodent diversity will permit the circulation of additional viruses and strains (Plyusnina et al. 2011).

In the New World, outbreaks of hantavirus pulmonary syndrome in humans or the prevalence in rodents of causal viruses, such as Sin Nombre virus (SNV) in North America and related pathogenic viruses in Central and South America, appear to be negatively correlated with the diversity of rodent species, only some of which are competent hosts (Dizney and Ruedas, 2009; Ruedas et al. 2004; Suzán et al. 2008). These conclusions suffer from a certain lack of robustness, relying on comparison between a single outbreak and a single negative site (Ruedas et al. 2004), only 2 selected viruses and rodent hosts amongst others (Suzán et al. 2008), and a relationship based on 5 sites that shows no trend whatsoever in infection prevalence in rodents as the Simpson diversity index $\left(D_{s}\right)$ decreases from about 0.75 to 0.45 at 4 sites, but a marked increase as $D_{s}$ reaches c. $0 \cdot 38$ at the fifth site, with marked inter-annual variation (Dizney and Ruedas, 2009). The L-shaped graph suggests that $D_{s}$ is not actually a good predictor of infection prevalence until perhaps some extreme limiting condition is reached (as seen in Allan et al. 2003 and Fig. 1). A model of a simple system in which one non-host rodent species is added to a single reservoir species yielded exactly the prediction to be expected; the existence of a second species that competes with the competent murid host leads to reduction or even elimination of infection at a critical level of the competitor's population (Peixoto and Abramson, 2006). No more convincing is the experimental study in which all non-reservoir species were removed at experimental forest edge sites in Panama, leaving only Zygodontomys brevicauda and Oligoryzomys fulvescens, reservoirs for Calabazo and Choclo viruses, respectively (Suzán et al. 2009). Despite claims of significant differences between control and experimental plots, in fact only 3 out of 16 observations for the latter ( 2 observations, before and after manipulation, for each of 8 plots) show any higher prevalence for hantavirus than the controls (Suzán's Fig. 3), and there was no correlation between species diversity and sero-prevalence (Suzán's Fig. 2B). Furthermore, sero-conversion in each observation period before and after manipulation is presented as absolute numbers (Suzán's Fig. 4) without correction for different densities of these rodent species on the control and experimental plots, i.e. were not "rates" and are therefore impossible to interpret. Overall, the evidence for a dilution effect is overstated.

An alternative element of biodiversity, predator diversity, was investigated with respect to $\mathrm{SNV}$ prevalence in reservoir deer mice (Peromyscus maniculatus) on 8 faunistically de-pauperate Californian Channel Islands, where these mice predominate amongst rodents and interspecific competition is low (Orrock et al. 2011). The strongest single positive correlate of SNV prevalence was precipitation, possibly related to virus survival in the environment (Linard et al. 2007) or food availability for rodents, but positive effects of island area and negative effects of predator diversity (which co-varied) were also significant in a multi-variate model. The point is made that types of predators, avian or mammalian, and their degree of specialization, may be as important as diversity in driving rodent population fluctuations and thereby variable virus transmission potential (Orrock et al. 2011). Conclusions about the real importance of predator diversity for rodenthantavirus systems, especially in mainland contexts, are hard to draw from this study, given the complex and currently unknown precise role of predators in regulating their prey populations in different circumstances, as elaborated by Ostfeld and Holt (2004). Only where predators or dominant competitors are really instrumental in reducing populations of key hosts for zoonotic infections will their presence control risk of human infection (Packer et al. 2003; Ostfeld and Holt, 2004), most likely through simple host density-dependent effects (Begon, 2008), but this is by no means invariably related to increased biodiversity as much as to a specific change in community composition.

\section{CONCLUSIONS}

\section{Biodiversity versus community structure}

If one were to reverse the order of most of the studies in support of the dilution effect, starting with the non-competent host and then adding the competent one, the natural conclusion would be that biodiversity causes disease amplification, the precise opposite of the dilution effect (see, for example, the penultimate paragraph of Allan et al. 2009). As many of the examples above show, it is community composition rather than biodiversity that is crucial, largely because of the pathogen-specific differential use of (potential) host species in transmission cycles. In North America, for example, the deer that are claimed to act as dilution hosts for Lyme borreliosis act as reservoir hosts for Anaplasma phagocytophilum, the causative agent of Human Granulocytic Anaplasmosis.

Despite conclusions and examples such as this, there is an emerging assumption that the species competent to transmit human zoonoses of many sorts are most likely to thrive in newly impoverished environments (Keesing et al. 2010a) due to the immuno-ecological trade-off between effective immunity and 'fast' life-history traits (Hawley and 
Altizer, 2011). According to this framework, those vertebrates most likely to display resilience to anthropogenic habitat disturbance would be those with high reproductive output and rates of population growth, traits that might impose constraints on developmentally costly immune systems through energy limitation or oxidative stress (Dowling and Simmons, 2009). While comparisons between closely-related vertebrate species have provided some support for this concept amongst birds (Lee et al. 2006; Lee et al. 2008; Martin et al. 2006), amongst rodents, Peromyscus species did not differ in immunocompetence per se, but simply used different immunological strategies that were not determined solely by their reproductive pace of life (Martin et al. 2007). At higher taxonomic levels, any evolved tradeoff balance is unlikely to produce a uniform outcome that precludes species with relatively 'slow' lifehistory traits (e.g. ungulates rather than rodents) from acting as reservoir/transmission hosts, otherwise we should have nothing to fear from swine or primates as sources of zoonotic infections. Past pathogen challenge over evolutionary as well as ecological time-scales is arguably the strongest selection pressure determining the level of investment in immunity, that may itself impose differential constraints on life-history traits (Horrocks et al. 2011). Identifying cause and effect under a wide range of natural conditions, which depends on developing the correct indices of parasite load and immune responses ("immunobiotic pressure") (Horrocks et al. 2011), must precede any simplistic conclusion that anthropogenic changes in community structure will typically favour species more competent to act as hosts to all sorts of parasites/pathogens.

It is clear from the examples in this review that simple changes in indices of biodiversity through the loss or gain of certain species may either dilute or amplify the risk of infection through direct or indirect effects, depending on the parasite/pathogen species under study and its transmission cycle. As Ostfeld and LoGiudice (2003) pointed out, the effects of simulated biodiversity loss depend absolutely on the order in which species are removed (or added); "... individual species have effects that are both idiosyncratic and strongly contingent on the identities of the other members of the community....".

\section{Panglossian extension ad absurdam - "biodiversity protects against infection"}

Against this background of disparity in natural hostparasite systems, the 4 features identified as likely to predispose vector-borne disease systems to the dilution effect (Table 1, based on Ostfeld and Keesing 2000b) have been extended to other types of host-parasite interactions (Johnson and Thieltges, 2010; Keesing et al. 2006; Ostfeld and Keesing, 2000a): (1) parasites infect multiple host species, but with a low degree of between-species transmission and rates that are more frequency- than densitydependent; (2) the presence of species within the community that [adversely] affect parasite transmission to the focal host and the resulting disease risk; (3) the domination of low diversity communities by highly competent host species; (4) within more diverse communities, a greater fraction of species that interfere with parasite transmission in some way. Clearly each criterion applies differentially amongst the diverse range of natural disease systems and even in the same system in different ecological contexts. The impact of community structure on infection prevalence has been studied in disease systems involving not only humans, but also hosts of importance to livestock, wild food stocks, crops and conservation. Results consistently show that the effect of increasing biodiversity in all its various forms (non-competing hosts of variable transmission competence, predators, competitors) is not uniform; amplification or neutral effects have been observed as much as reduced infection prevalence. About $60 \%$ of emergent pathogens have three or more reservoir host species (in addition to humans) (Woolhouse and GowtageSequeria, 2005), indicating that pathogen dynamics driven by a multiplicity of hosts is a more realistic picture for emerging infectious diseases (Begon, 2008). Indeed, the non-specialist host relationships of B. burgdorferi s.s. strains, together with those of their tick vector, may account for the rapid emergence of Lyme disease in the USA (Kurtenbach et al. 2006). Any synergistic effects of multiple hosts on shared pathogens would enhance persistence and abundance (Begon, 2008).

This more balanced view undermines the panglossian generalization that biodiversity is likely to protect against infection (Dobson et al. 2006; Pongsiri and Roman, 2007; Swaddle and Calos, 2008; Pongsiri et al. 2009; Keesing et al. 2010), an attractive claim repeatedly used to underpin policy and funding decisions. Studies of the sort that in the past have reported the range of natural biotic interactions that affect pathogen transmission cycles and resultant zoonotic hazards for humans are now couched in terms of the 'biodiversity-buffers-disease' paradigm. Any undesirable loss of biodiversity, whatever its precise measure or meaning (e.g. biotic homogenization at specific and genetic levels as local species are replaced by exotics, de-forestation and loss of structural diversity, reduced community composition and assemblages of organisms from microbes to vertebrates), is linked to "effects on human health", but always with the emphasis on emergence or reemergence, rather than on reduction, of health risks (Pongsiri et al. 2009).

One obvious exception to the negative relationship between biodiversity and disease risk arises because more or new hosts may harbour more or new 
pathogens at both local and global scales. The hotspots of biodiversity in the tropics are not diseasepoor havens. Even if spatial patterns are not precisely aligned (Dobson et al. 2008), general patterns of vertebrate and parasite diversity show concurrent latitudinal gradients increasing towards the tropics (Guernier et al. 2004; Hechinger and Lafferty, 2005). Furthermore, the pan-global analysis of emerging infectious diseases between 1940 and 2004 identified mammalian species richness (considered as a proxy for wildlife species richness) as a significant determinant of zoonotic disease risk of wildlife origin (but not of vector-borne disease risk) (Jones et al. 2008). "....why there are apparently more diseases in the species-rich tropics is an entirely separate matter" (Ostfeld and Keesing, 2000a) is a point of view not shared by everyone, even if biogeographical patterns of species richness on one hand and anthropogenic diversity loss on the other require different policy and management options (Keesing et al. 2010). The ecological circumstances may differ markedly, but, until shown otherwise, it is reasonable to assume a similar range of functional processes of pathogen transmission, requiring an explanation as to why the rules of global patterns should not apply at local scales.

It is of course legitimate to identify biodiversity changes as one possible set of causes for disease emergence, but not to preach that high biodiversity always protects against disease. That is little more than a straw man, an argument easily dismantled and dismissed by those whose commercial and political ambitions jeopardise the future of biodiversity and ecosystem function. It adds only fragility to the case for creating a new UN organisation, the Intergovernmental Science-Policy Platform on Biodiversity and Ecosystem Services (IPBES) (Larigauderie and Mooney, 2010; Marris, 2010). There is also the danger of driving public health policy by this inconsistent and therefore unreliable rule of thumb, as these ideas start to infiltrate the medical literature (Costello et al. 2009) and the web (e.g. http:// www.cohabnet.org/, http://caha.org.au/ and http:// www.diversitas-international.org/activities/research/ ecohealth/highlights), including professional medical web sites (http://www.globalpulsejournal.com/blog/ index.php/category/national-public-health-week/). The panglossian approach is doomed to fail; we must accept that not everything about biodiversity is necessarily positive for humans.

\section{ACKNOWLEDGEMENTS}

We thank Robert Lane, Jean Tsao, David Rogers and Paul Johnson for useful comments on the original draft.

\section{FINANCIAL SUPPORT}

This research received no specific grant from any funding agency, commercial or not-for-profit sectors.

\section{REFERENCES}

Allan, B. F., Dutra, H. P., Goessling, L. S., Barnett, K., Chase, J. M., Marquis, R. J., Pang, G., Storch, G. A., Thach, R. E. and Orrock, J. L. (2011). Invasive honeysuckle eradication reduces tick-borne disease risk by altering host dynamics. Proceedings of the National Academy of Sciences, USA 107, 18523-18527.

Allan, B. F., Goessling, L. S., Storch, G. A. and Thach, R. E. (2010). Identification of reservoir hosts for Amblyomma americanum-associated zoonoses using bloodmeal analysis. Emerging Infectious Diseases 16, 433-440.

Allan, B. F., Keesing, F. and Ostfeld, R. S. (2003). Effect of forest fragmentation on Lyme disease risk. Conservation Biology 17, 267-272.

Allan, B. F., Langerhaus, R. B., Ryberg, W. A., Landesman, W. J., Griffin, N. W., Katz, R. S., Oberle, B. J., Schutzenhofer, M. R. Smyth, K. N., de St Maurice, A., Clark, L., Crooks, K. R., Hernandez, D.E., McLean, R. G., Ostfeld, R.S. and Chase, J. M. (2009). Ecological correlates of risk and incidence of West Nile virus in the United States. Oecologia 158, 699-708.

Apperson, C. S., Levine, J. F., Evans, T. L., Braswell, A. and Heller, J. (1993). Relative utilization of reptiles and rodents as hosts by immature Ixodes scapularis (Acari: Ixodidae) in the coastal plain of North Carolina, USA. Experimental and Applied Acarology 17, 719-731.

Begon, M. (2008). Effects of host diversity on disease dynamics. In Infectious Disease Ecology: Effects of Ecosystems on Disease and of Disease on Ecosystems. (ed. Ostfeld, R. S., Keesing, F. and Eviner, V. T.), pp. 12-29. Princeton University Press, Princeton. NJ, USA.

Bogh, C., Clarke, S.E., Walraven, G. E. L. and Lindsay, S. W. (2002). Zooprophylaxis, artefact or reality? A paired-cohort study of the effect of passive zooprophylaxis on malaria in The Gambia. Transactions of the Royal Society of Tropical Medicine and Hygiene 96, 593-596.

Borer, E. T., Mitchell, C. E., Power, A. G. and Seabloom, E. W. (2009) Consumers indirectly increase infection risk in grassland food webs. Proceedings of the National Academy of Sciences, USA 106, 503-506.

Bouma, M. J. and Rowland, M. (1995). Failure of passive zooprophylaxis: cattle ownership in Parkistan is associated with a higher prevalence of malaria. Transactions of the Royal Society of Tropical Medicine and Hygiene 89, 351-353.

Brisson, D., Dykhuizen, D. E. and Ostfeld, R. S. (2008). Conspicuous impacts of inconspicuous hosts on the Lyme disease epidemic. Proceedings of the Royal Society of London, B 275, 227-235.

Bruemmer, C. M., Rushton, S. P., Gurnell, J., Lurz, P. W. W. Nettleton, P., Sainsbury, A.W., Duff, J.P., Gilray, J. and McInnes, C. J. (2010). Epidemiology of squirrelpox in grey squirrels in the UK. Epidemiology \& Infection 138, 941-950.

Brunner, J. L. and Ostfeld, R. S. (2008). Multiple causes of variable tick burdens on small-mammal hosts. Ecology 89, 2259-2272.

Burri, C., Bastic, V., Maeder, G., Patalas, E. and Gern, L. (2011). Microclimate and the zoonotic cycle of tick-borne encephalitis virus in Switzerland. Fournal of Medical Entomology 48, 615-627.

Carlson, J. C., Dyer, L.A., Omlin, F.X. and Beier, J.C. (2009). Diversity cascades and malaria vectors. Fournal of Medical Entomology 46, 460-464.

Civitello, D. J., Flory, S. L. and Clay, K. (2008). Exotic grass invasion reduces survival of Amblyomma americanum and Dermacentor variabilis ticks (Acari: Ixodidae). Fournal of Medical Entomology 45, 867-872.

Clover, J. R. and Lane, R.S. (1995). Evidence implicating nymphal Ixodes pacificus (Acari: Ixodidae) in the epidemiology of Lyme disease in California. American Fournal of Tropical Medicine and Hygiene 53, 237 240 .

Costello, A., Abbas, M., Allen, A., Ball, S., Bellamy, R., Friel, S., Grace, N., Johnson, A., Kett, M., Lee, M., Levy, C., Maslin, M., McCoy, D., McGuire, B., Montgomery, H., Napier, D., Pagel, C., Patel, J., de Oliveira, J. A. P., Redclift, N., Rees, H., Rogger, D., Scott, J., Stephenson, J., Twigg, J., Wolff, J. and Patterson, C. (2009). Managing the health effects of climate change. The Lancet 373, 1693-1733.

Craine, N. G., Randolph, S.E. and Nuttall, P.A. (1995). Seasonal variation in the rôle of grey squirrels as hosts of Ixodes ricinus, the tick vector of the Lyme disease spirochaete, in a British woodland. Folia Parasitologica 42, 73-80.

Dalkvist, T., Sibly, R. M. and Topping, C. J. (2011). How predation and landscape fragmentation affect vole population dynamics. PLoS ONE 6, e22834

Daszak, P., Cunningham, A. A. and Hyatt, A. D. (2001). Anthropogenic environmental change and the emergence of infectious diseases in wildlife. Acta Tropica 78, 103-116.

Diaz, S., Fargione, J., Chapin, F.S. I. and Tilman, D. (2006). Biodiversity loss threatens human well-being. PLoS Biology 4, 1300-1305. 
Dizney, L. J. and Ruedas, L. A. (2009). Increased host species diversity and decreased prevalence of Sin Nombre virus. Emerging Infectious Diseases 15, 1012-1018.

Dobson, A. P. (2004). Population dynamics of pathogens with multiple host species. The American Naturalist 164 (Suppl.) S64-S78.

Dobson, A., Cattadori, I., Holt, R.D., Ostfeld, R.S., Keesing, F., Krichbaum, K., Rohr, J. R., Perkins, S. E. and Hudson, P. J. (2006). Sacred cows and sympathetic squirrels: the importance of biological diversity to human health. PLoS Medicine 3, 714-718.

Dobson, A., Lafferty, K. D., Kuris, A.M., Hechinger, R.F. and Jetz, W. (2008). Homage to Linneaus: How many parasites? How many hosts? Proceedings of the National Academy of Sciences, USA 105, (Suppl. 1), 11482-11489.

Dobson, A. D. M., Finnie, T. J.R. and Randolph, S.E. (2011). A modified matrix model to describe the seasonal population ecology of the European tick Ixodes ricinus. Fournal of Applied Ecology 48, 1017-1028.

Dobson, A.D. M. and Randolph, S. E. (2011). Modelling the effects of recent changes in climate, host density and acaricide treatments on population dynamics of Ixodes ricinus in the UK. Fournal of Applied Ecology 48, 1029-1037.

Dowling, D. K. and Simmons, L. W. (2009). Reactive oxygen species as universal constraints in life-history evolution. Proceedings of Royal Society of London, B 276, 1737-1745.

Elias, S. P., Lubelczyk, C. B., Rand, P.W., Lacombe, E. H., Holman, M. S. and Smith, R. P. J. (2006). Deer browse resistant exoticinvasive understory: an indicator of elevated human risk of exposure to Ixodes scapularis (Acari: Ixodidae) in southern coastal Maine woodlands. Fournal of Medical Entomology 43, 1142-1152.

Elton, C.S. (1958). The Ecology of Invasions by Animals and Plants. Methuen, London, UK.

Ezenwa, V. O., Godsey, M. S., King, R. J. and Guptill, S. C. (2006). Avian diversity and West Nile virus: testing associations between biodiversity and infectious disease risk. Proceedings of Royal Society of London, B 273, 109-117.

Falco, R. C., McKenna, D. F., Daniels, T. J., Nadelman, R. B., Nowakowski, J., Fish, D. and Wormser, G.P. (1999). Temporal relation between Ixodes scapularis abundance and risk for Lyme disease associated with erythema migrans. American Fournal of Epidemiology 149, 771-776

Gern, L., Estrada-Peña, A., Frandsen, F., Gray, J., J. S., G., Jaenson, T. G. T., Jongejan, F., Kahl, O., Korenberg, E., Mehl, R. and Nuttall, P. A. (1998). European reservoir hosts of Borrelia burgdorferi sensu lato. Zentralblatt für Bakteriologie 287, 196-204.

Giardina, A. R., Schmidt, K. A., Schauber, E. M. and Ostfeld, R. S. (2000). Modeling the role of songbirds and rodents in the ecology of Lyme disease. Canadian Fournal of Zoology 78, 2184-2197.

Gilbert, L., Norman, R., Laurenson, M.K., Reid, H.W. and Hudson, P. J. (2001). Disease persistence and apparent competition in a three-host community: an empirical and analytical study of large-scale, wild populations. Fournal of Animal Ecology 70, 1053-1061

Glass, G. E., Schwarz, B. S., Morgan III, J. M., Johnson, D. T. Noy, P. M. and Israel, E. (1995). Environmental risk factor for Lyme disease identified with geographic information systems. American fournal of Public Health 85, 944-948.

Gray, J. S., Kahl, O., Janetzki, C. and Stein, J. (1992). Studies on the ecology of Lyme disease in a deer forest in County Galway, Ireland. Fournal of Medical Entomology 29, 915-920.

Guernier, V., Hochberg, M. E. and Guegan, J.-F. (2004). Ecology drives the worldwide distribution of human diseases. PLoS Biology 2, 0740 .

Hamer, G. L., Chaves, L.F., Anderson, T.K., Kitron, U. D., Brawn, J. D., Ruiz, M. O., Loss, S. R., Walker, E. D. and Goldberg, T. L. (2011). Fine-scale variation in vector host use and force of infection drive localized patterns of West Nile virus transmission. PLoS ONE 6, e23767.

Hanincova, K., Ogden, N. H., Diuk-Wasser, M., Pappas, C. J., Iyer, R., Fish, D., Schwartz, I. and Kurtenbach, K. (2008). Fitness variation of Borrelia burgdorferi sensu stricto strains in mice. Applied and Environmental Microbiology 74, 153-157.

Hanski, I., Hansson, L. and Henttonen, H. (1991). Specialist predators, generalist predators, and the microtine rodent cycle. Fournal of Animal Ecology 60, 353-367.

Hartemink, N. A., Davis, S. A., Reiter, P., Hubálek, Z. and Heesterbeek, J. A. P. (2007). Importance of bird-to-bird transmission for the establishment of West Nile virus. Vector-Borne and Zoonotic Diseases 7, 575-584.

Hawley, D. M. and Altizer, S. M. (2011). Disease ecology meets ecological immunology: understanding the links between organismal immunity and infection dynamics in natural populations. Functional Ecology 25, 48-60.

Hechinger, R. F. and Lafferty, K. D. (2005). Host diversity begets parasite diversity: bird final hosts and trematodes in snail intermediate hosts. Proceedings of the Royal Society of London, B 272, 1059-1066.

Hess, A. D. and Hayes, R. O. (1970). Relative potentials of domestic animals for zooprophylaxis against mosquito vectors of encephalitis American Fournal of Tropical Medicine and Hygiene 19, 327-334.

Holt, R. D. and Lawton, J.H. (1994). The ecological consequences of shared natural enemies. Annual Review of Ecology and Systematics 25, 495-520.

Hoodless, A. N., Kurtenbach, K., Nuttall, P. A. and Randolph, S. E. (2002). The impact of ticks on pheasant territoriality. Oikos 96, 245-250.

Hoogstraal, H. (1981). Changing patterns of tick-borne diseases in modern society. Annual Review of Entomology 26, 75-99.

Horobik, V., Keesing, F. and Ostfeld, R. S. (2007). Abundance and Borrelia burgdorferi-infection prevalence of nymphal Ixodes scapularis ticks along forest-field edges. EcoHealth 3, 262-268.

Horrocks, N. P. C., Matson, K. D. and Tieleman, B. I. (2011). Pathogen pressure puts immune defense into perspective. Integrative and Comparative Biology 51, 563-576.

Hubálek, Z. and Halouzka, J. (1998). Prevalence rates of Borrelia burgdorferi sensu lato in host-seeking Ixodes ricinus ticks in Europe. Parasitology Research 84, 167-172.

Hubálek, Z. and Halouzka, J. (1999). West Nile virus-a reemerging mosquito-borne viral disease in Europe. Emerging Infectious Diseases 5, 643-650.

Hudson, P. J., Rizzoli, A., Rosa, R., Chemini, C., Jones, L. D. and Gould, E. A. (2001). Tick-borne encephalitis virus in northern Italy: molecular analysis, relationships with density and seasonal dynamics of Ixodes ricinus. Medical and Veterinary Entomology 15, 304-313.

Humair, P.-F. and Gern, L. (1998). Relationship between Borrelia burgdorferi sensu lato species, red squirrels (Sciurus vulgaris) and Ixodes ricinus in enzootic areas in Switzerland. Acta Tropica 69, 213-227.

Humair, P.-F., Postic, D., Wallich, R. and Gern, L. (1998). An avian reservoir (Turdus merula) of the Lyme borreliosis spirochetes. Zentralblatt für Bakteriologie 287, 521-538.

Jensen, P. M. and Frandsen, F. (2000). Temporal risk assessment for Lyme borreliosis in Denmark. Scandinavian Fournal of Infectious Diseases 35, 539-544.

Jensen, P. M., Hansen, H. and Frandsen, F. (2000). Spatial risk assessment for Lyme borreliosis in Denmark. Scandinavian fournal of Infectious Diseases 35, 545-550.

Johnson, P. T. J., Hartson, R. B., Larson, D. J. and Sutherland, D. R. (2008). Diversity and disease: community structure drives parasite transmission and host fitness. Ecology Letters 11, 1017-1026.

Johnson, P. T. J., Lund, P. J., Hartson, R. B. and Yoshino, T. P. (2009). Community diversity reduces Schistosoma mansoni transmission, host pathology and human infection risk. Proceedings of Royal Society of London, B 276, 1657-1663.

Johnson, P. T. J. and Thieltges, D. W. (2010). Diversity, decoys and the dilution effect: how ecological communities affect disease risk. Fournal of Experimental Biology 213, 961-970.

Jones, K. E., Patel, N. G., Levy, M. A., Storeygard, A., Balk, D., Gittleman, J. L. and Daszak, P. (2008). Global trends in emerging infectious diseases. Nature, London 451, 990-994.

Keesing, F., Belden, L. K., Daszak, P., Dobson, A., Harvell, C. D., Holt, R.D., Hudson, P., Jolles, A., Jones, K. E., Mitchell, C. E., Myers, S. S., Bogich, T. and Ostfeld, R. S. (2010). Impacts of biodiversity on the emergence and transmission of infectious diseases. Nature, London 468, 647-652.

Keesing, F., Brunner, J., Duerr, S., Killilea, M., LoGiudice, K., Schmidt, K., Vuong, H. and Ostfeld, R. S. (2009). Hosts as ecological traps for the vector of Lyme disease. Proceedings of the Royal Society, B 276, 3911-3919.

Keesing, F., Holt, R. D. and Ostfeld, R.S. (2006). Effects of species diversity on disease risk. Ecology Letters 9, 485-498.

Kilpatrick, M., Daszak, P., Jones, M. J., Marra, P.P. and Kramer, L. D. (2006). Host heterogeneity dominates West Nile virus transmission. Proceedings of the Royal Society of London, B 273, 2327-2333. Kimura, K., Isogal, E., Isogal, H., Kamewaka, Y., Nishikawa, T. Ishii, N. and Fujii, N. (1995). Detection of Lyme disease spirochetes in the skin of naturally infected wild sika deer (Cervus nippon yesoensis) by PCR. Applied and Environmental Microbiology 61, 1641-1642.

Komar, N., Langevin, S., Hinten, S., Nemeth, N., Edwards, E., Hettler, D., Davis, B., Bowen, R. and Bunning, M. (2003). Experimental infection of North American birds with the New York 1999 strain of West Nile virus. Emerging Infectious Diseases 9, 311-322. 
Kostiukov, M. A., Alekseev, A. N., Bulychev, V.P. and Gordeeva, Z. E. (1986). [Experimental evidence for infection of Culex pipiens L. mosquitoes by West Nile fever virus from Rana ridibunda Pallas and its transmission by bites]. Meditsinskaya Parazitologiya i Parazitarnye Bolezni 6, 76-78.

Kurtenbach, K., Carey, D., Hoodless, A. N., Nuttall, P.A. and Randolph, S. E. (1998a). Competence of pheasants as reservoirs for Lyme disease spirochetes. Fournal of Medical Entomology 35, 77-81.

Kurtenbach, K., Hanincova, K., Tsao, J. I., Margos, G., Fish, D. and Ogden, N. H. (2006). Fundamental processes in the evolutionary ecology of Lyme borreliosis. Nature Reviews Microbiology 4, 660-669.

Kurtenbach, K., Peacey, M. F., Rijpkema, S. G. T., Hoodless, A. N., Nuttall, P. A. and Randolph, S.E. (1998b). Differential transmission of the genospecies of Borrelia burgdorferi sensu lato by game birds and small rodents in England. Applied and Environmental Microbiology 64, 1169-1174.

Kurtenbach, K., Sewell, H., Ogden, N.H., Randolph, S.E. and Nuttall, P. A. (1998c). Serum complement as a key factor in Lyme disease ecology. Infection and Immunity 66, 1248-1251.

Lane, R. S. and Quistad, G. B. (1998). Borreliacidal factor in the blood of the western fence lizard (Sceloporus occidentalis). Fournal of Parasitology 84, 29-34.

Larigauderie, A. and Mooney, H. A. (2010). The Intergovernmental science-policy Platform on Biodiversity and Ecosystems Services: moving a step closer to an IPCC-like mechanism for biodiversity. Current Opinion in Environmental Sustainability 2, 9-14.

Lee, K. A., Martin, L. B., Hasselquist, D., Ricklefs, R. E. and Wikelski, M. (2006). Contrasting adaptive immune defenses and blood parasite prevalence in closely related Passer sparrows. Oecologia 150, 383-392.

Lee, K. A., Wikelski, M., Robinson, W.D., Robinson, T.R. and Klasing, K. C. (2008). Constitutive immune defences correlate with life-history variables in tropical birds. Fournal of Animal Ecology 77, $356-363$.

Linard, C., Lamarque, P., Heyman, P., Ducoffre, G., Lutasu, V., Tersago, K., Vanwambeke, S. O. and Lambin, E. F. (2007) Determinants of the geographic distribution of Puumala virus and Lyme borreliosis infections in Belgium. International Fournal of Health Geographics 6, 15-29.

LoGiudice, K., Duerr, S. T.K., Newhouse, M. J., Schmidt, K. A., Killilea, M. E. and Ostfeld, R.S. (2008). Impact of host community composition on Lyme disease risk. Ecology 89, 2841-2849.

LoGiudice, K., Ostfeld, R. S., Schmidt, K. A. and Keesing, F. (2003) The ecology of infectious disease: Effects of host diversity and community composition on Lyme disease risk. Proceedings of the National Academy of Sciences, USA 100, 567-571.

Loss, S. R., Hamer, G. L., Walker, E. D., Ruiz, M. O., Goldberg, T. L., Kitron, U. and Brawn, J. D. (2009). Avian host community structure and prevalence of West Nile virus in Chicago, Illinois. Oecologia 159, 415-424. Macdonald, G. (1956). Epidemiological basis of malaria control. Bulletin of the World Health Organization 15, 613-626.

Marina, C. F., Bond, J. G., Casas, M., Munoz, J., Orozco, A., Valle, J. and Williams, T. (2011). Spinosad as an effective larvicide for control of Aedes albopictus and Aedes aegypti, vectors of dengue in southern Mexico. Pest Management Science 67, 114-121.

Marris, E. (2010). UN body will assess ecosystems and biodiversity. Nature, London 465, 859-859.

Martin, L. B., Hasselquist, D. and Wikelski, M. (2006). Investment in immune defense is linked to pace of life in house sparrows. Oecologia 147, $565-575$.

Martin, L. B., Weil, Z. M. and Nelson, R. J. (2007). Immune defense and reproductive pace of life in Peromyscus mice. Ecology 88, 2516-2528.

Matuschka, F.-R., Fischer, P., Heiler, M., Richter, D. and Spielman, A. (1992). Capacity of European animals as reservoir hosts for the Lyme disease spirochete. Fournal of Infectious Diseases 165, 479-483.

Matuschka, F.-R., Heiler, M., Eiffert, H., Fischer, P., Lotter, H. and Spielman, A. (1993). Diversionary role of hoofed game in the transmission of Lyme-disease spirochetes. American Fournal of Tropical Medicine and Hygiene 48, 693-699.

Matuschka, F.-R., Schinkel, T.W., Klug, B., Spielman, A. and Richter, D. (2000). Relative importance of European rabbits for Lyme disease spirochaetes. Parasitology 121, 297-302.

Miller, D. L., Mauel, M. J., Baldwin, C. L., Burtle, G., Ingram, D. Hines, M. E. and Frazier, K.S. (2003). West Nile virus in farmed alligators. Emerging Infectious Diseases 9, 794-799.

Murgue, B., Murri, S., Zientara, S., Durand, B., Durand, J.-P. and Zeller, H. (2001). West Nile outbreak in horses in southern France, 2000: the return after 35 years. Emerging Infectious Diseases 7, 692-696.
Nah, K., Kim, Y. and Lee, J. M. (2010). The dilution effect of the domestic animal population on the transmission of $P$. vivax malaria. Fournal of Theoretical Biology 266, 299-306.

Nupp, T. E. and Swihart, R. K. (1996). Effect of forest patch area on population attributes of white-footed mice (Peromyscus leucopus) in fragmented landscapes. Canadian Fournal of Zoology 74, 467-472.

Nupp, T. E. and Swihart, R. K. (1998). Effects of forest fragmentation on population attributes of white-footed mice and eastern chipmunks. Fournal of Mammalogy 79, 1234-1243.

Ogden, N. H., Nuttall, P. A. and Randolph, S. E. (1997). Natural Lyme disease cycles maintained via sheep by co-feeding ticks. Parasitology 115, 591-599.

Ogden, N.H. and Tsao, J.I. (2009). Biodiversity and Lyme disease: dilution or amplification? Epidemics 1, 196-206.

Orrock, J. L., Allan, B. F. and Drost, C. A. (2011). Biogeographic and ecological regulation of disease: prevalence of Sin Nombre virus in island mice is related to island area, precipitation, and predator richness. American Naturalist 177, 691-697.

Ostfeld, R. S. (2009). Biodiversity loss and the rise of zoonotic pathogens. Clinical Infectious Diseases 15, 40-43.

Ostfeld, R. S., Canham, C. D., Oggenfuss, K., Winchcombe, R. J. and Keesing, F. (2006). Climate, deer, rodents, and acorns as determinants of variation in Lyme-disease risk. PLoS Biology 4, e145.

Ostfeld, R. S. and Holt, R. D. (2004). Are predators good for your health? Evaluating evidence for top-down regulation of zoonotic disease reservoirs. Frontiers in Ecology and the Environment 2, 13-20.

Ostfeld, R. S. and Keesing, F. (2000a). Biodiversity and disease risk: the case of Lyme disease. Conservation Biology 14, 722-728.

Ostfeld, R. S. and Keesing, F. (2000b). The function of biodiversity in the ecology of vector-borne zoonotic diseases. Canadian fournal of Zoology 78, 2061-2078.

Ostfeld, R. S. and LoGiudice, K. (2003). Community disassembly, biodiversity loss, and the erosion of an ecosystem service. Ecology 84, 1421-1427.

Packer, C., Holt, R. D., Hudson, P. J., Lafferty, K. D. and Dobson, A. P. (2003). Keeping herds healthy and alert: implications of predator control for infectious disease. Ecology Letters 6, 797-802.

Paddock, C. D. and Yabsley, M. J. (2007). Ecological havoc, the rise of white-tailed deer, and the emergence of Amblyomma americanum-associated zoonoses in the United States. Current Topics in Microbiology and Immunology 315, 289-324.

Peixoto, I. D. and Abramson, G. (2006). The effect of biodiversity on the hantavirus epizootic. Ecology 87, 873-879.

Perkins, S. E., Cattadori, I. M., Tagliapietra, V., Rizzoli, A. and Hudson, P. J. (2006). Localized deer absence leads to tick amplification. Ecology 87, 1981-1986.

Piesman, J. (2002). Ecology of Borrelia burgdorferi sensu lato in North America. In Lyme Borreliosis Biology, Epidemiology and Control (ed. Gray, J.S., Kahl, O., Lane, R. S. and Stanek, G.), pp. 223-250. CABI, Wallingford, UK.

Piesman, J. and Gern, L. (2008). Lyme borreliosis in Europe and North America. In Ticks: Biology, Disease and Control (ed. Bowman, A. S. and Nuttall, P. A.), pp. 220-252. Cambridge University Press, Cambridge, UK.

Plyusnina, A., Krajinovic, L. C., Margaletic, J., Niemimaa, J., Nemirov, K., Lundkvist, A., Markotic, A., Miletic-Medved, M., Avsic-Zupanc, T., Henttonen, H. and Plyusnin, A. (2011). Genetic evidence for the presence of two distinct hantaviruses associated with Apodemus mice in Croatia and analysis of local strains. Fournal of Medical Virology 83, 108-114.

Pongsiri, M. J. and Roman, J. (2007). Examining the links between biodiversity and human health: an interdisciplinary research intiative at the U.S. Environmental Protection Agency. EcoHealth 4, 82-85.

Pongsiri, M. J., Roman, J., Ezenwa, V. O., Goldberg, T. L., Koren, H. S., Newbold, S. C., Ostfeld, R. S., Pattanayak, S. K. and Salkeld, D. J. (2009). Biodiversity loss affects global disease ecology. BioScience 59, 945-954.

Power, A. G. and Mitchell, C. E. (2004). Pathogen spillover in disease epidemics. American Naturalist 164, S79-S89.

Pugliese, A. and Rosa, R. (2008). Effect of host populations on the intensity of ticks and the prevalence of tick-borne pathogens: how to interpret the results of deer exclosure experiments. Parasitology 135, 1531-1544.

Randolph, S. E. (2004). Tick ecology: processes and patterns behind the epidemiological risk posed by ixodid ticks as vectors. Parasitology 129, S37-66.

Randolph, S. E. and Steele, G. M. (1985). An experimental evaluation of conventional control measures against the sheep tick Ixodes ricinus $(\mathrm{L})$ 
(Acari: Ixodidae). II. The dynamics of the tick-host interaction. Bulletin of Entomological Research 75, 501-518.

Randolph, S. E. and Storey, K. (1999). Impact of microclimate on immature tick-rodent interactions (Acari: Ixodidae): implications for parasite transmission. Fournal of Medical Entomology 36, 741-748.

Reiter, P. (2008). Global warming and malaria: knowing the horse before hitching the cart. Malaria fournal 7, S3.

Rizzoli, A., Hauffe, H. C., Tagliapietra, V., Neteler, M. and Rosa, R. (2009). Forest structure and roe deer abundance predict tick-borne encephalitis risk in Italy. PLoS ONE 4, e4336.

Roche, B. and Guégan, J.-F. (2011). Ecosystem dynamics, biological diversity and emerging infectious diseases. Comptes Rendus Biologies 334, 385-392.

Rosa, R., Pugliese, A., Norman, R. and Hudson, P. J. (2003). Thresholds for disease persistence in models for tick-borne infections including non-viraemic transmission, extended feeding and tick aggregation. Fournal of Theoretical Biology 224, 359-376.

Ruedas, L. A., Salazar-Bravo, J., Tinnin, D. S., Armien, B., Caceres, L., Garcia, A., Diaz, M. A., Gracia, F., Suzán, G., Peters, C. J., Yates, T. L. and Mills, J. N. (2004). Community ecology of small mammal populations in Panama following an outbreak of Hantavirus pulmonary syndrome. Fournal of Vector Ecology 29, 177-191.

Saul, A. (2003). Zooprophylaxis or zoopotentiation: the outcome of introduced animals on vector transmission is highly dependent on the mosquito mortality while searching. Malaria fournal 2, 32 .

Sbrana, E., Tonry, J.H., Xiao, S. Y., da Rosa, A.P., Higgs, S. and Tesh, R. B. (2005). Oral transmission of West Nile virus in a hamster model. American fournal of Tropical Medicine and Hygiene 72, 325-329.

Sota, T. and Mogi, M. (1989). Effectiveness of zooprophylaxis in malaria control-a theoretical enquiry, with a model for mosquito populations with two bloodmeal hosts. Medical and Veterinary Entomology 3, 337-345.

Spielman, A., Wilson, M. L., Levine, J. F. and Piesman, J. (1985). Ecology of Ixodes dammini-borne human babesiosis and Lyme disease. Annual Review of Entomology 30, 439-460.

Stafford (III), K. C., Cartter, M. L., Magarelli, L. A., Ertel, S.-H. and Mshar, P. A. (1998). Temporal correlations between tick abundance and prevalence of ticks infected with Borrelia burgdorferi and increasing incidence of Lyme disease. Fournal of Clinical Microbiology 36, 1240-1244. Steinbach Elwell, L. C., Kerans, B. L. and Zickovich, J. (2009). Hostparasite interactions and competition between tubificid species in a benthic community. Freshwater Biology 54, 1616-1628.

Suzán, G., Armien, N., Mills, J. N., Marce, E., Ceballos, G., Avila, M., Salazar-Bravo, J., Ruedas, L.A., Armien, B. and Yates, T. L. (2008). Epidemiological considerations of rodent community composition in fragmented landsacpes in Panama. Fournal of Mammalogy 89, 634-690. Suzán, G., Marce, E., Giermakowski, J. T., Mills, J. N., Ceballos, G., Ostfeld, R. S., Armien, B., Pascale, J. M. and Yates, T. L. (2009). Experimental evidence for reduced rodent diversity causing increased hantavirus prevalence. PLoS ONE 4, e5461.

Swaddle, J.P. and Calos, S.E. (2008). Increased avian diversity is associated with lower incidence of human West Nile infection: observation of the dilution effect. PLoS ONE 3, e2488.

Swei, A., Ostfeld, R. S., Lane, R. S. and Briggs, C. J. (2011). Impact of the experimental removal of lizards on Lyme disease risk. Proceedings of the Royal Society of London, B 278, 2970-2978.

Talleklint, L. and Jaenson, T. G. T. (1994). Transmission of Borrelia burgdorferi s.l. from mammal reservoirs to the primary vector of Lyme borreliosis, Ixodes ricinus (Acari: Ixodidae), in Sweden. Fournal of Medical Entomology 31, 880-886.

Talleklint, L. and Jaenson, T. G. T. (1996). Relationship between Ixodes ricinus density and prevalence of infection with Borrelia-like spirochetes and density of infected ticks. Fournal of Medical Entomology 33, 805-811.
Tersago, K., Schreurs, A., Linard, C., Verhagen, R., Van Dongen, S. and Leirs, H. (2008). Population, environmental, and community effects on local bank vole (Myodes glareolus) Puumala virus infection in an area with low human incidence. Vector-Borne and Zoonotic Diseases 8, 235-244.

Tersago, K., Verhagen, R. and Leirs, H. (2011a). Temporal variation in individual factors associated with hantavirus infection in bank voles during an epizootic: implications for Puumala virus transmission dynamics. VectorBorne and Zoonotic Diseases 11, 715-721.

Tersago, K., Verhagen, R., Servais, A., Heyman, P., Ducoffre, G. and Leirs, H. (2009). Hantavirus disease (nephropathia epidemica) in Belgium: effects of tree seed production and climate. Epidemiology and Infection 137, 250-256.

Tersago, K., Verhagen, R., Vapalahti, O., Heyman, P., Ducoffre, G. and Leirs, H. (2011b). Hantavirus outbreak in Western Europe: reservoir host infection dynamics related to human disease patterns. Epidemiology and Infection 139, 381-390.

Thieltges, D. W., Bordalo, M. D., Cabalerro Hernandez, A., Prinz, K. and Jensen, K. T. (2009a). Ambient fauna impairs parasite transmission in a marine parasite-host system. Parasitology 135, 1111-1116.

Thieltges, D. W., Reise, K., Prinz, K. and Jensen, K. T. (2009b). Invaders interfere with native parasite-host interactions. Biological Invasions 11, 1421-1429.

Tilman, D., Knops, J. M. H., Wedin, D., Reich, P. B., Ritchie, S. A. and Siemann, E. (1997). Influence of functional diversity and composition on ecosystem processes. Science 277, 1300-1302.

Tilman, D., Reich, P. B. and Knops, J. M. H. (2006). Biodiversity and ecosystem stability in a decade-long grassland experiment. Nature, London 441, 629-632.

Tsao, J.I., Wootton, J. T., Bunikis, J., Luna, M. G., Fish, D. and Barbour, A. G. (2004). An ecological approach to preventing human infection: vaccinating wild mouse reservoirs intervenes in the Lyme disease cycle. Proceedings of the National Academy of Sciences, USA 101, 18159-18164.

Turell, M. J., Dohm, D. J., Sardelis, M. R., O’Guinn, M. L., Andreadis, T. G. and Blow, J. A. (2005). An update on the potential of North American mosquitoes (Diptera: Culicidae) to transmit West Nile virus. Fournal of Medical Entomology 42, 57-62.

van Buskirk, J. and Ostfeld, R. S. (1995). Controlling Lyme disease by modifying the density and species composition of tick hosts,. Ecological Applications 5, 1133-1140.

Vapalahti, O., Mustonen, J., Lundkvist, A., Henttonen, H., Plyusnin, A. and Vaheri, A. (2003). Hantavirus infections in Europe. Lancet Infectious Diseases 3, 653-661.

Voltaire (1759). Candide (edn. Bair L.), Bantam Dell, New York, USA. Ward, J. S. and Mervosh, T. L. (2008). Strategies to reduce browse damage on eastern white pine (Pinis strobus) in southern New England, USA. Forest Ecology and Management 255, 1559-1567.

Williams, S. C., Ward, J. S., Worthley, T. E. and Stafford (III), K. C. (2009). Managing Japanese barberry (Ranunculales: Berberidaceae) infestations reduces black-legged tick (Acari: Ixodidae) abundance and infection prevalence with Borrelia burgdorferi (Spirochaetales: Spirochaetaceae). Environmental Entomology 38, 977-984.

Wilson, M. L., Litwin, T.S., Gavin, T.A., Capkanis, M. C., Maclean, D. C. and Spielman, A. (1990). Host-dependent differences in feeding and reproduction of Ixodes dammini (Acari: Ixodidae). Fournal of Medical Entomology 27, 945-954.

Woolhouse, M. E. J. and Gowtage-Sequeria, S. (2005). Host range and emerging and reemerging pathogens. Emerging Infectious Diseases 11, 1842-1847.

Zeman, P. and Januska, J. (1999). Epizootiologic background of dissimilar distribution of human cases of Lyme borreliosis and tick-borne encephalitis in a joint endemic area. Comparative Immunology, Microbiology and Infectious Diseases 22, 247-260. 